\title{
Diversification of innovation strategies of Polish industrial processing enterprises depending on their size after the global financial crisis
}

\section{Aleksander Jakimowicz ${ }^{1}$ iD, Daniel Rzeczkowski}

\begin{abstract}
The purpose of this article is to define an innovation strategy for Polish industrial processing enterprises for 2012-2014, i.e. after a negative external shock which escalated in 2008-2010 and was associated with a global financial crisis. Various types of enterprises (small, medium, large), geographic scope of markets, forms of innovation activity of enterprises, decisions by enterprises regarding innovation implementation types, methods of product development and process innovations by enterprises, and forms of eco-innovation which are the most frequent in industrial processing, were studied as well as barriers to innovation. Overall, seven detailed research hypotheses were statistically verified using a chi-square test for independence. Subsequently, due to a high number of variables taken into account in the study as well as the necessity of providing a detailed description of the relationships between them, a correspondence analysis was employed. The analysis was aimed at reducing the multi-dimensional space where the studied phenomena occur to a space of fewer dimensions, in this case, to two dimensions. This allows for a careful examination of the co-occurrence of the phenomena using biplots. A relatively slight tendency of enterprises towards innovation was established as well as caution in its implementation, which may result from the relative persistence of the exogenous shock effects. At the same time, there is a clear tendency towards eco-innovation in a broader perspective, with a slow decrease - as presumed by enterprises - in the importance of barriers to innovation. Practical conclusions following from the study show the need to emphasize the benefits of innovation, especially eco-innovation, in pro-innovation policy, which will help to avoid the adverse effects of the external shock - psychological barriers and

1 Aleksander Jakimowicz, Ph.D. habilitatus of economic sciences, Department of World Economy, Institute of Economics, Polish Academy of Sciences, Palace of Culture and Science, 1 Defilad Sq., 00-901 Warsaw, Poland, e-mail: ajakimowicz@inepan.waw.pl (ORCID ID: 0000-0003-2522-082X), corresponding author.

2 Daniel Rzeczkowski, Ph.D., Department of Market and Consumption, Faculty of Economic Sciences, University of Warmia and Mazury in Olsztyn, 4 M. Oczapowskiego St., 10-719 Olsztyn, Poland, e-mail: daniel.rzeczkowski@uwm.edu.pl (ORCID ID: 0000-0002-8458-5987).
\end{abstract}


excessive caution in innovation planning and implementation. The article presents an original, unique, and comprehensive analysis of the relationships between sixty-three variables describing the innovation activity of enterprises. Therefore, the value of the article lies in an original and strictly empirical approach to the problems of innovation in the industrial processing sector, which means that the study presented in it might become a possible model for such analyses in the future.

Keywords: industrial processing enterprises, innovation strategy, barriers to innovation, eco-innovations, correspondence analysis

\section{INTRODUCTION}

The issue of diversity in the innovation strategy of Polish enterprises in industrial processing is a complex economic problem due to a number of factors to be considered in the study. This article extensively researches the problem, including the relationships between and co-occurrence of sixty-three variables. Statistical data were from 2012-2014, thus after the exogenous innovation shock which was a result of the global financial crisis. The period under consideration is particularly interesting due to prevailing innovation pessimism as well as corporate efforts to overcome it.

In the research part of the article, the relationships between the variables and their co-occurrence are analyzed. The main determinant of innovation activity of firms proved to be their type, i.e. divided into small, mediumsized and large enterprises. That was to be expected since the typology mentioned hinges upon the number of employees, annual turnover and/ or annual balance sheet total, which means the supply of enterprises with factors of production (labor and capital). The higher availability of production factors leads to greater chances for innovation because market competition forces their implementation. The dependencies were tested between the enterprise type and such variables as the geographic scope of the market in which it operates, the forms of innovation activity, types of innovation implemented, methods of developing products and process innovations, barriers to innovation, as well as the benefits of eco-innovation for the environment obtained both while producing goods or providing services and through the use of a purchased product or service by end users. Only the variables pertaining to forms of innovation activity had no confirmed dependencies, which is natural since only innovative firms were studied. However, in this case, the data also shed light on the diversity in innovation strategy of an enterprise depending on its size. Another issue to study was the co-occurrence of variables describing the innovation activity of firms, barriers to innovation and types of enterprises. It allowed multiple surprising relationships between the variables to be discovered, with some confirming 
the conclusions arrived at earlier and some disproving them. Statistical data analysis was performed using Statistica 13.3 software.

Based on empirical and theoretical studies, a research gap has been identified, consisting in insufficient identification of factors determining innovation strategies of Polish industrial processing enterprises after the global financial crisis. This concerns, in particular, investigation of the reasons behind an overall reluctance to innovate, the importance of barriers to innovation and identifying new ideas of enterprises towards innovations in the present conditions. The primary added value consists in presenting the complexity of the problem and multi-level relations between the examined variables, explaining the low willingness of enterprises to invest, discovering the relatively low importance of barriers to innovation and the emergence of a new strategy oriented towards eco-innovations.

\section{LITERATURE REVIEW}

The dependency between the innovation activity of companies and changes in the economic situation is relatively strong, yet inconclusive (Kijek, 2018). As claimed in the literature on the subject, the global financial crisis proved that the innovative Polish companies discussed here turned out to be not very resistant to negative external shocks. From the perspective of susceptibility of companies to changes in the economic situation, one needs to single out two time periods: the global financial crisis of 2008-2010 and the gradual economic recovery of 2010-2012. In the first time period, firms rarely used innovation resources, which led to a sudden decrease in innovation commercialization indicators - that is why it is dubbed an innovation crisis. In the second time period, the decrease in innovation commercialization rates was smaller, but at the same time, a reduction in the frequency of use of innovation resources by firms was noted, which indicated a sense of uncertainty and pessimism regarding further possibilities of the growth of markets for innovative products. Thus, the years 2010-2012 are called a period of innovation pessimism (Wziątek-Kubiak \& Pęczkowski, 2019). The innovation activity of foreign companies was subject to similar changes.

Considering the innovation strategies of companies during the economic crisis, one may encounter the view that maintaining persistent innovation activity in the studied period may considerably help it to increase the survivability of an enterprise and its competitive capacity in the last stages of an economic slowdown. In addition, increased frequency of the use of innovation resources in times of crisis can alleviate its effects and shorten an innovation pessimism period. Certain consistency across innovation 
strategies, before and in a crisis, increases the resistance of companies to external shocks and reduces the likelihood of disturbances in the path of innovation during a downturn. The major role of good relations between the management and trade unions is also highlighted as well as of labor relations in improving the company's survivability of a crisis (Antonioli et al., 2013). The persistence of innovation in times of crisis may be sustained through both public support for enterprises and their own innovation strategies. In Italy, for instance, one may observe limitation of the said persistence primarily to process innovation (Antonioli \& Montresor, 2018).

The issue of innovation in enterprises plays a central role in the European Union's development plans. The basic priorities of the Europe 2020 Strategy include smart growth, sustainable growth, and inclusive growth. The first of these concerns the development of a knowledge- and innovation-based economy, increasing the potential of the digital economy caused by higher investment expenditures for research and development, and improvement of the educational quality (Gasz, 2014). This requires allocating $3 \%$ of the European Union GDP for development and growth investments (Europe 2020: A European strategy..., 2010). It can be observed that the Gross Domestic Expenditure on the R\&D indicator (GERD) and its dynamics have varied significantly in individual EU countries in recent years. In 2010-2016, its highest values, fluctuating around the threshold determined by the Europe 2020 Strategy, were recorded in Sweden, Finland, Denmark, Germany, and Austria. In Poland, this indicator demonstrated a growing trend, changing from 0.56 in 2007 to 1.03 in 2017. In 2017, GERD for the entire European Union was $2.07 \%$, which indicated a rather low probability of reaching the target value of 3\% in 2020 (Eurostat, 2019). However, it turns out that failing to meet this condition does not impede the innovation capability of enterprises too much, as with the development of digitalization the number of patents granted by the European Patent Office has increased throughout the entire European Union (MacGregor Pelikánová, 2019).

The issues of innovation, economic growth and development, and welfare are closely related to entrepreneurship (Raport z badania..., 2018). It appears that innovative entrepreneurs, measured by the level of innovation in the initial phase of their entrepreneurial activity (TEA - Total Early-stage Entrepreneurial Activity), are the most numerous in the European countries with the highest rates of economic growth and higher levels of real national income. However, the research also indicates the absence of a close relationship between a higher degree of entrepreneurial activity, consisting in the establishment of new companies, and economic development, which may result from the varied motivations of entrepreneurs in individual EU countries. It is assumed that entrepreneurs of the Schumpeter type, i.e. innovators applying creative 
destruction, are prevalent in developed countries, which naturally contributes to economic growth, while less innovative shopkeepers are the most common in developing countries (Crudu, 2019; Block, Fisch, \& van Praag, 2017).

Studies of the Norwegian economy demonstrated that from the perspective of the innovation of enterprises, their endowment with a set of unique resources or assets and the ability to operate in an innovationfriendly socio-economic environment are of critical importance. It appears that factors affecting the probability of undertaking innovation included four attributes related to the enterprise and two attributes of a regional nature. The most important characteristics concerning the enterprises included their size, industrial sector, availability of R\&D staff, and own-financed research and development work, while the environmental features were related to the size and the quality of the region. The most important factor affecting the probability of innovation proved to be the size of the enterprise. Larger enterprises turned out to be more innovative than the smaller ones. This observation is consistent with basic economics, as sizeable enterprises can allocate much larger resources or assets to their innovative activity than smaller enterprises. With regard to the business sector, it was found that although the probability of innovation was similar in all industry sectors, it proved to be significantly lower in commercial and transport sectors. The availability of research and development personnel increases the probability of innovation, but this effect is not significantly higher in comparison to enterprises that do not have such staff. On the other hand, internal financing of research and development works demonstrated a great positive effect on enterprises undertaking innovation (Lorentzen \& Jakobsen, 2016).

The size of the enterprise is one of the most important internal properties, indicating its ability to undertake innovation. This feature is usually defined based on the Cobb-Douglas production function, which contains such independent variables as labor input and capital input (Cobb \& Douglas, 1928). This approach has been assumed in the European Union, where the classification of enterprises into small, medium and large enterprises is based on employment limits and the value of annual turnover and/or annual balance sheet total (Commission Regulation (EU) No. 651/2014). The best variable describing innovation capability of enterprises would be the value of innovation capital, but this notion is not clearly defined in the literature. This emerged from the combination of two economic terms: capital, in the meaning of the factor of production, and innovation. Generally speaking, innovation capital covers a bundle of the firm's resources or assets, which provides complementary services in the process of creating and commercializing new knowledge. It also contains elements necessary in the processes of developing new products or services, such as science, culture, technology, and networks of cooperation 
(Kijek, 2012). In this approach, examination of an innovation strategy of enterprises equals examination of their innovation capital.

The caution of Polish enterprises in undertaking innovation activity may result from mutual distrust which impedes cooperation between firms. It can be observed that significant disproportions exist in Poland with regard to innovation of enterprises in the regional perspective, with the largest of them concerning the share of sold production of new or substantively improved (modernized) goods in the sold value of industry. Additionally, the research discovered the occurrence of unsatisfactory cooperation between enterprises in the area of innovation. This suggests the existence of distrust between firms as regards innovation activity, which may result in the lack of mutual benefits from the implementation of innovations (Golejewska, 2018). Similar conclusions can be derived from the Norwegian experience. A very important factor increasing the probability of innovation in enterprises is the socio-economic environment supporting innovative activity. Here, the size and the quality of the region where the enterprise is situated play an important role. In Norway, the highest innovation activity is demonstrated by enterprises located in the capital region, with the highest number of inhabitants and variety of institutions, while the lowest activity characterizes enterprises located in rural areas, in regions with a population below 10,000 . The quality of the region, reflected in the existence or lack of existence of regional network of cooperation between enterprises, is also of high significance. Regional cooperation between enterprises in the area of innovation significantly increases the probability of undertaking innovations by enterprises. Innovation indicators are higher for those enterprises that are involved in regional cooperation, compared to those that do not cooperate with others (Lorentzen \& Jakobsen, 2016). The quality of the human and organizational environment is also important for the diffusion of innovation, understood as spreading information on innovative products or technologies by external communication channels, among both purchasers and entrepreneurs (Baran, 2010).

Research into enterprise innovation strategies proves that at least five types of such strategies can be named: (1) a science-based strategy, (2) an investment-based strategy, (3) an IT/process-oriented strategy, (4) a process/product-oriented strategy and (5) an IT/product-oriented strategy. The enterprises following a strategy of the first or last type are high-profile innovators; if they focus on investments (2) and/or a process or product (4), they are low-profile innovators; whereas enterprises following an IT/processoriented strategy (3) represent medium-profile innovators. A substantial number of firms are able to modify their strategies already in a three-year time frame. The socio-economic environment affecting the innovation activity 
of enterprises, including such elements as demand prospects, intensity of competition, and technological opportunities, change quickly and companies ought to be capable of adapting to them via strategy changes. Firms following strategies (1), (3), and (5), i.e. based on science, oriented to IT/process and $\mathrm{IT} /$ product, achieve the greatest benefits from strategy changes - that is why they are referred to as net winners. On the other hand, companies following the least innovative strategy (4), i.e. a process/product-oriented one, tend to be net losers after a strategy change. Such patterns of innovation strategies of companies rely on structural changes occurring in highly-developed economies, e.g. in Switzerland (Hollenstein, 2018, 2019).

Comparative studies among companies in such countries as Poland, the Czech Republic, and Hungary rendered it possible to distinguish five various innovation strategy patterns: low profile pattern firms, virtual firms, spillover absorbers in process innovation, firms on the science-based innovation path and firms pursuing supplier orientation. This typology was based on companies operating in four manufacturing industries: food and beverages, automotive, pharmaceuticals and electronics. Each of these strategies involves various forms of innovation activity and different innovation outputs (Balcerowicz, Pęczkowski, \& Wziątek-Kubiak, 2012; Wziątek-Kubiak, Balcerowicz, \& Pęczkowski, 2013). These patterns of innovation are also widespread in other EU Member States, which indicates that countries themselves may exert a limited impact on the heterogeneity of the innovation dynamics of companies (Srholec \& Verspagen, 2008).

Undertaking eco-innovation currently appears to be a separate innovation strategy of Polish enterprises, whose aim is to reach sustainable economic development as a result of reducing the negative effect of industrial production on the environment and responsible use of natural resources. Their importance in economic life has been continuously growing and in the future, they might be a key factor in business competitiveness. Eco-innovation involves the introduction of new environmentally-friendly production processes and technologies, which is intended to prevent environment degradation and reduce biodiversity. The environmental benefits of such an innovation strategy can occur either during the generation of a product or service, or through the use of a purchased product or service by end users. In Poland, between 2010 and 2012, the eco-innovation activity of industrial enterprises was insignificant, which led to its classification into countries catching up in this regard (Gałązka, 2017; Węgrzyn, 2013). This should not be surprising as that was a period of innovation pessimism. However, the study described in this article implies that Polish industrial companies are becoming increasingly interested in eco-innovation. 


\section{RESEARCH METHODS}

Two statistical methods were employed in the study: Pearson's chi-square test for independence and correspondence analysis. A chi-square test for independence is used in analyses of the relationship between two nominal variables. The chi-square statistic is used to establish a test value. The test is carried out by comparing empirical values actually achieved and expected values calculated with the assumption of no relationship between the variables (null hypothesis). If the difference between these values is statistically significant, a relationship between the variables is assumed (Pearson, 1900). The hypotheses tested concerned relations between the variables defining the types of enterprises and their innovation activity, as per the contingency tables. A correspondence analysis is a descriptive and exploratory method of analyzing two-way and multi-way tables that contain metrics describing the correspondence between the rows and columns (Bourdieu, 1996) and allows the co-occurrence of phenomena to be studied. It is intended to reconstruct the distances between points representing rows and columns of two-way and multi-way tables in a space with a fewer number of dimensions, usually in a two-dimensional space. Calculations are performed in a way that maintains as much information as possible about the diversity of rows and columns. The result of applying this method is a graphical representation of the structure of relationships between the variables included in the tables (Benzécri, 1992; Greenacre, 1984).

The popularity of correspondence analysis in economic research is on the rise, although it seems reasonable to briefly present what underlies it. The first step in correspondence analysis is the construction of a correspondence matrix. It consists of relative frequencies, achieved by dividing entries in a multi-way table by their grand total. A row profile matrix can then be calculated, achieved by dividing relative frequencies in each row of the correspondence matrix by the sum of all frequencies in the corresponding row. A column profile matrix is calculated in a similar way; it is an effect of dividing each relative frequency in a given column by the sum of frequencies corresponding to the said column. The next step is determination of average profiles. An average row profile is arrived at by dividing the summary row of a multi-way table by the grand total. It is a sum of all the relative frequencies in the columns of a correspondence matrix. An average column profile is calculated by dividing the summary column in a multi-way table by the grand total. It is also produced by a sum of the relative frequencies in the rows of a correspondence matrix.

In correspondence analysis, the chi-square metric is used to calculate the distances between row profiles and column profiles. Inertia, associated with 
this metric, is an equivalent of variance - which is well-known in statistics. Total inertia shall be understood as a measure of the dispersion of row or column profiles around their average profiles. Inertia calculated for rows is equal to the inertia calculated for columns. To reduce the dimension of the phenomenon tested, which - as mentioned - is the principal goal of correspondence analysis, the method of singular value decomposition of the correspondence matrix is employed (Borg \& Groenen, 2010; Greenacre, 2007). Total inertia is constituted by the sum of the squares of eigenvalues. The percentage measure is used to select the number of dimensions, which is the quotient of the sum of squares of the first two eigenvalues, after ordering them in a nongrowing manner, and the total value of the chi-square statistic. If this ratio equals at least $75 \%$, it is recognized that a two-dimensional space adequately reflects the initial values. Having selected the recommended number of dimensions, the coordinates of row and column profiles are calculated in a new coordinate system. This provides a graph - a biplot - presenting a set of points that reflects the relationships between the rows and columns (Greenacre, 2010). In this article, row and column profile standardization was applied for interpretation of results. It allows the coordinates for rows and columns to be determined in the same coordinate system. It is then possible to simultaneously analyze points representing row profiles and column profiles. Thus, the row coordinates were calculated based on the row profile matrix and the column coordinates were then calculated on the basis of the column profile matrix.

The concepts of the quality of a point as well as of a row or column masses also need to be explained. Row mass is the total of the relative frequencies in a given row, and column mass is the total of the relative frequencies in a given column. One can also say that row mass is an average column profile, and that column mass is an average row profile. The row or column masses provide information about the importance of a given row or column. On the other hand, relative frequencies define how one unit of mass is distributed across the cells of the table. Quality is about reflecting a row or column in a selected coordinate system. With regard to the chi-square metric, the quality of a point shall be understood as a quotient of the square of the distance between the selected point and the origin of coordinate system adopted and the square of the same distance in a coordinate system with the maximum number of dimensions. Although the quality of a point may range from zero to one, the higher this measure is, the better the representation of a given row or column in a space with an agreed number of dimensions. 


\section{DATA ANALYSIS AND STUDY RESULTS}

\section{General characteristics of the companies studied}

Available data concern 10,244 Polish innovative enterprises in the industrial processing sector, divided into three types: small, medium and large. According to Article 2 (Annex I) of Commission Regulation (EU) No. 651/2014, a small enterprise means an economic operator employing fewer than 50 persons whose annual turnover and/or annual balance sheet total does not exceed EUR 10 million. Medium-sized enterprises are those that employ fewer than 250 persons and their annual turnover does not exceed EUR 50 million, and/or their annual balance sheet total does not exceed EUR 43 million. If the business entity exceeds the limits set for the medium-sized enterprise, it is called a large enterprise. The analyzed database does not include micro-enterprises which, according to their definition, employ less than 10 persons and whose annual turnover and/or annual balance sheet total does not exceed EUR 2 million. This is consistent with the logic of the production function since with low resources of production factors it is difficult to carry out innovative activity. Table 1 illustrates all three types of enterprises studied and their numbers.

Table 1. Types of enterprises, their numbers, and variable codes

\begin{tabular}{lcc}
\hline \multicolumn{3}{c}{ Types of enterprise } \\
\hline Name & Code & Number \\
\hline Small (up to 49 employees) & FR_1 & 3,594 \\
Medium-sized (between 50 and 249 employees) & FR_2 & 5,198 \\
Large (250 or more employees) & FR_3 & 1,452 \\
Total & & 10,244 \\
\hline
\end{tabular}

The distribution of the companies by type is shown on a histogram in Figure 1. Medium-sized enterprises account for $51 \%$ of the companies studied, small $-35 \%$, and large - $14 \%$. Further research showed that the type of company is of utmost importance from the standpoint of its innovation activity. 


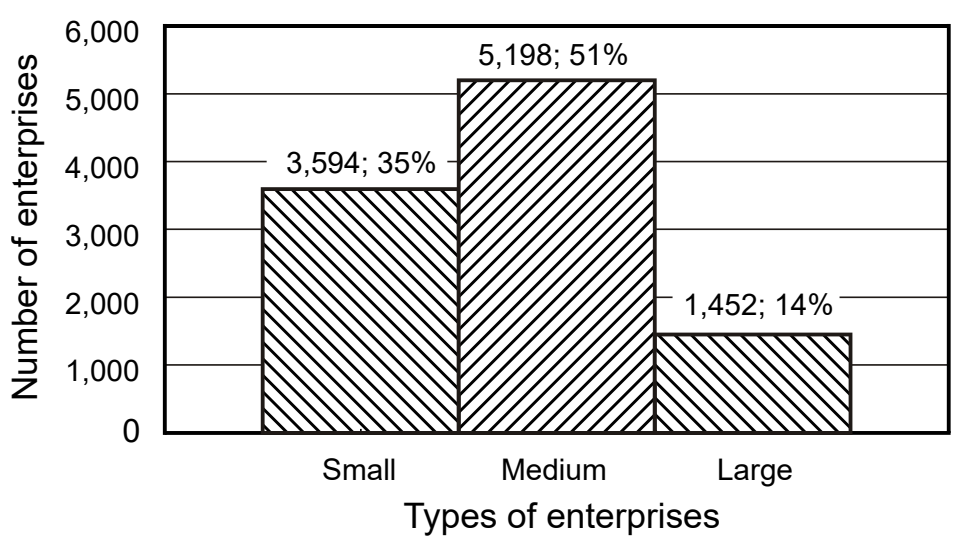

Figure 1. Histogram presenting the companies by number and type (small, medium-sized, large)

\section{The scope of the geographic market of the companies studied}

A market is to be understood as an economic institution consisting of a series of mechanisms that allow for establishing contact between producers and consumers in order to enable the exchange of different types of goods, services, and information. Economic institutions define the rules of the game in the society by introducing certain restrictions on interactions among people (North, 1990, p. 3). They are essentially focused on the development of markets, for they include sets of rules, enforcement mechanisms, as well as organizations supporting market transactions (Building Institutions..., 2002, p. 4). This study involved the division of the market according to its geographic scope and the following market types were singled out: local, domestic, EU, and non-EU markets. Table 2 reveals the number of individual enterprise types by market.

Table 2. Types of enterprises and the geographical scope of their markets

\begin{tabular}{llllll}
\hline \multirow{2}{*}{$\begin{array}{l}\text { Types of } \\
\text { enterprise }\end{array}$} & \multirow{2}{*}{ Code } & \multicolumn{4}{l}{ The scope of the geographic market (name and code) } \\
\cline { 3 - 6 } & & Local - & Domestic & EU Member & Non-EU \\
& & RK1 & - RK2 & States - RK3 & countries - RK4 \\
\hline Small & FR_1 & 2,953 & 2,653 & 1,789 & 777 \\
Medium-sized & FR_2 & 4,261 & 4,330 & 3,854 & 2,331 \\
Large & FR_3 & 1,196 & 1,284 & 1,314 & 1,052 \\
\hline
\end{tabular}


There was a research question posed about the existence of a relationship between the type of enterprise and the geographic scope of the market in which a given firm operates. To verify this, a chi-square test for independence is performed. The following research hypotheses were formulated:

$H_{0}$ : market geographic coverage does not depend on the type of enterprise; $H_{1}$ : market geographic coverage depends on the type of enterprise.

Verification results of the null hypothesis are presented in Table 3. One may observe that with a significance level $\alpha=0.05$, the inequality $\mathrm{p}<\alpha$ is preserved, thus the null hypothesis has to be rejected. It must be concluded that market geographic coverage depends on the enterprise type.

Table 3. Results of the verification of the $H_{0}$ hypothesis regarding the independence of market geographic coverage from an enterprise type

\begin{tabular}{llll}
\hline$\chi^{2}$ value & Degrees of freedom & Significance level $(\alpha)$ & $p$-value \\
\hline $1,186.464$ & 2 & 0.05 & 0.000 \\
Decision & Since $p<\alpha, H_{0}$ needs to be rejected in favor of $H_{1}$ \\
\hline
\end{tabular}

A more thorough analysis of relationships between market geographic coverage and enterprise types requires a correspondence analysis. Table 4 presents the coordinates of points representing the types of enterprises (rows) and the market geographic coverage (columns) as well as the statistics of the quality of the solution. The evaluation of the quality of mapping of the points representing the rows and columns is provided in the last column of Table 4. Point quality is the measure of representation of individual rows (columns) in a space with fewer dimensions. It ranges from 0 to 1 . The closer to one, the better the point analyzed is represented. Here, the quality of mapping of the individual rows and columns is excellent since the measure reached its maximum -1 . This only happens when two dimensions explain $100 \%$ of the total inertia.

Table 4. Coordinates of rows (enterprise types) and columns (market geographic coverage) as well as the statistics of the solution quality

\begin{tabular}{|c|c|c|c|c|}
\hline \multicolumn{5}{|c|}{ Row coordinates } \\
\hline \multirow{2}{*}{ Row } & \multicolumn{2}{|c|}{ Dimension } & \multirow{2}{*}{ Mass } & \multirow{2}{*}{ Quality } \\
\hline & Axis 1 & Axis 2 & & \\
\hline FR_1 & -0.193975 & 0.011217 & 0.294020 & 1.000000 \\
\hline FR_2 & 0.037472 & 0.014391 & 0.531626 & 1.000000 \\
\hline
\end{tabular}




\begin{tabular}{|c|c|c|c|c|}
\hline \multicolumn{5}{|c|}{ Row coordinates } \\
\hline \multirow{2}{*}{ Row } & \multicolumn{2}{|c|}{ Dimension } & \multirow{2}{*}{ Mass } & \multirow{2}{*}{ Quality } \\
\hline & Axis 1 & Axis 2 & & \\
\hline FR_3 & 0.212853 & 0.024963 & 0.174354 & 1.000000 \\
\hline \multicolumn{5}{|c|}{ Column coordinates } \\
\hline \multirow{2}{*}{ Column } & \multicolumn{2}{|c|}{ Dimension } & \multirow{2}{*}{ Mass } & \multirow{2}{*}{ Quality } \\
\hline & Axis 1 & Axis 2 & & \\
\hline RK_1 & -0.134306 & 0.012351 & 0.302583 & 1.000000 \\
\hline RK_2 & -0.068122 & -0.003784 & 0.297438 & 1.000000 \\
\hline RK_3 & 0.078923 & 0.023306 & 0.250306 & 1.000000 \\
\hline RK_4 & 0.274906 & 0.021526 & 0.149673 & 1.000000 \\
\hline
\end{tabular}

The precise relationships between enterprise type and market geographic coverage may be illustrated in a two-dimensional space. Graphic interpretation of these dependencies is presented in Figure 2. The relevant instances of co-occurrence of the phenomena were marked with square frames. Small enterprises (FR_1) operate mainly in local and domestic markets, mediumsized enterprises (FR_2) sell their products on domestic and EU markets, and large enterprises (FR_3) cater to virtually all the market types. In the latter case, however, non-EU markets stand out. An insufficient interest of companies in the vast Community market can result from excessive red tape that paralyzes its operation, as admitted by E. Bieńkowska, European Commissioner for Internal Market, Industry, Entrepreneurship, and SMEs (Bieńkowska, 2015). Large enterprises have the greatest chance of bypassing this barrier because it is easier for them to move their operations to less bureaucratic markets outside Europe.

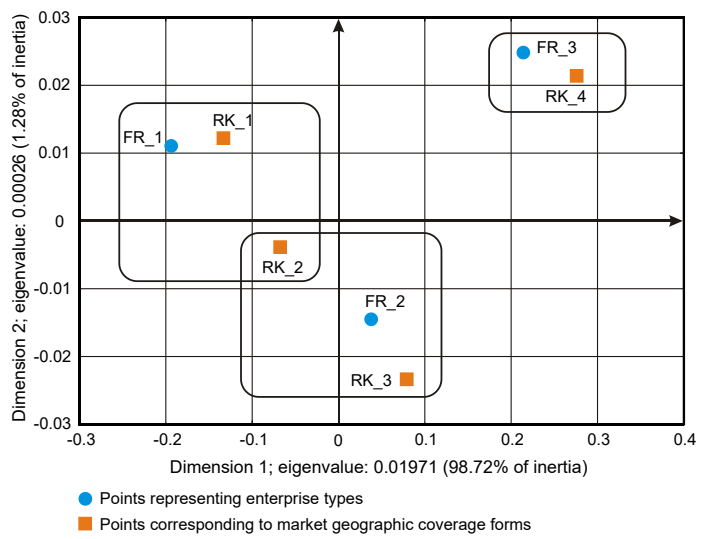

Figure 2. Biplot showing the co-occurrence of market geographic coverage forms and enterprise types 


\section{Characteristics of innovation activity of companies}

The innovation activity of enterprises involves: research and development that may be pursued individually by a firm or outsourced to other entities; purchasing technologically advanced machinery and technical equipment, product and process innovation software, acquisition of knowledge from external sources; training of personnel and marketing activities associated with the introduction of new or significantly improved products. Table 5 is a contingency table that includes the numbers relating to the variables which describe innovation activity by enterprise type.

Table 5. Numbers for individual forms of innovation activity, enterprise types, as well as variable codes

\begin{tabular}{|c|c|c|c|c|}
\hline Variables & Code & FR_1 & FR_2 & FR_3 \\
\hline R\&D within the entity & AK_1 & 168 & 705 & 450 \\
\hline R\&D outsourced & AK_2 & 82 & 420 & 308 \\
\hline Purchase of advanced technologies & AK_3 & 311 & 1202 & 674 \\
\hline $\begin{array}{l}\text { Purchase of process and product innovation } \\
\text { software }\end{array}$ & AK_4 & 173 & 653 & 421 \\
\hline $\begin{array}{l}\text { Acquisition of knowledge from external } \\
\text { sources for process and product innovation } \\
\text { implementation }\end{array}$ & AK_5 & 86 & 304 & 217 \\
\hline $\begin{array}{l}\text { Training of personnel directly associated with } \\
\text { the introduction of new or significantly improved } \\
\text { products and processes }\end{array}$ & AK_6 & 151 & 543 & 348 \\
\hline $\begin{array}{l}\text { Marketing associated with the introduction of } \\
\text { new or significantly improved products }\end{array}$ & AK_7 & 221 & 782 & 517 \\
\hline $\begin{array}{l}\text { Designing, improvement and change of the form, } \\
\text { appearance or utility of new or significantly } \\
\text { improved products }\end{array}$ & AK_8 & 161 & 633 & 412 \\
\hline $\begin{array}{l}\text { Preparations for the introduction of new or } \\
\text { significantly improved products or processes }\end{array}$ & AK_9 & 220 & 801 & 536 \\
\hline
\end{tabular}

A chi-square test for independence was carried out to determine the relationship between the types of enterprises and the variables describing their innovation activity. This required the formulation of the following research hypotheses:

$H_{0}$ : forms of innovation activity do not depend on the enterprise type; $H_{1}$ : forms of innovation activity depend on the enterprise type. 
Table 6 presents the calculations necessary to verify the null hypothesis of the independence of an innovation activity form from the enterprise type. In this case $\mathrm{p}>\alpha$, so the null hypothesis may not be rejected, which means the independence of a form of innovation activity from the enterprise type.

Table 6. Results of the verification of the hypothesis $H_{0}$ regarding the independence of an innovation activity form from the enterprise type

\begin{tabular}{llll}
\hline $\boldsymbol{\chi}^{2}$ value & Degrees of freedom & Significance level $(\alpha)$ & $\boldsymbol{p}$-value \\
\hline 25.807 & 16 & 0.05 & 0.05688 \\
Decision & Since $p>\alpha$, there are no grounds for rejecting $H_{0}$ \\
\hline
\end{tabular}

Even though $H_{0}$ is true, precise differentiation between forms of innovation activity by enterprise type may be performed by employing a correspondence analysis. Table 7 presents the coordinates of the points corresponding to the variables describing the innovation activity forms (rows) and those representing the enterprise types (column). The solution quality indicates complete representation of total inertia by two dimensions.

Table 7. Coordinates of the rows (forms of innovation activity) and the columns (enterprise types)

\begin{tabular}{lcccc}
\hline Row coordinates & \multicolumn{2}{c}{ Mass } & Quality \\
\cline { 2 - 3 } & Axis 1 & Axis 2 & 0.115 & 1.000 \\
\hline AK_1 & -0.017 & 0.023 & 0.070 & 1.000 \\
AK_2 & -0.116 & 0.034 & 0.190 & 1.000 \\
AK_3 & 0.055 & 0.029 & 0.108 & 1.000 \\
AK_4 & 0.003 & -0.005 & 0.053 & 1.000 \\
AK_5 & -0.026 & -0.043 & 0.091 & 1.000 \\
AK_6 & 0.017 & -0.017 & 0.132 & 1.000 \\
AK_7 & 0.007 & -0.027 & 0.105 & 1.000 \\
AK_8 & -0.011 & 0.003 & 0.135 & 1.000 \\
AK_9 & -0.005 & -0.022 & & \\
\hline Column coordinates & & Mass & Quality \\
\hline Column & & Dimension & & 1.000 \\
\cline { 2 - 3 } & Axis 1 & Axis 2 & & 1.000 \\
\hline FR_1 & 0.069 & -0.045 & 0.137 & 1.000 \\
FR_2 & 0.015 & 0.021 & 0.526 & \\
FR_3 & -0.051 & -0.015 & 0.338 & \\
\hline & & & \\
\hline
\end{tabular}


Graphic interpretation of the relationships between a form of innovation activity and the enterprise type is shown in Figure 3. It follows from the biplot that innovation activity is characteristic of medium-sized and large companies, represented by FR_2 and FR_3, since almost every form of innovation activity revolves around them, which is additional confirmation of the null hypothesis. In fact, small enterprises (FR_1) are located within the borders of the main square frame marked with a solid line, but only in its bottom right corner which points to relatively weak innovation activity of small companies. AK_2 is an isolated point, which means that all the companies, regardless of their type, relatively seldom outsource R\&D. Two square frames marked with a dotted line indicate diverse forms of innovation activity pursued by medium-sized (FR_2) and large (FR_3) companies. Medium-sized enterprises (FR_2) conduct their own R\&D (AK_1); in addition, they purchase advanced technologies (AK_3) and design new forms and appearances of products as part of product innovations (AK_8). On the other hand, large enterprises (FR_3) engage in various forms of activity, from AK_4 through AK_7 and AK_9; they involve the purchase of process and product innovation software, acquiring knowledge from external sources to implement such innovations, training of personnel, marketing efforts associated with the introduction of product and process innovations, as well as preparatory work related to the introduction of such innovations. In other words, the graph confirms the great potential for innovation in medium-sized and large enterprises. However, another phenomenon may also be observed - great distances between the points representing innovation activity forms and those corresponding to enterprise types. This means that companies do not hurry to undertake immediate and decisive action in terms of innovation, which is probably associated with the persistence in 2012-2014 of the effects of the exogenous shock of 2008-2010. This trend is indicative of a certain reluctance to innovate, though it is evident that firms are aware of the need for innovation. The phenomenon in question might be of a more or less rational nature, but it still means waiting for some improvement in the economic situation. Managers consider the current risks associated with undertaking innovation activity to be substantial; this makes them prepare for the introduction of new or improved products in the future when the conditions are more favorable. They await a change in the economic conditions that will reduce the risks involved with innovation activity. 


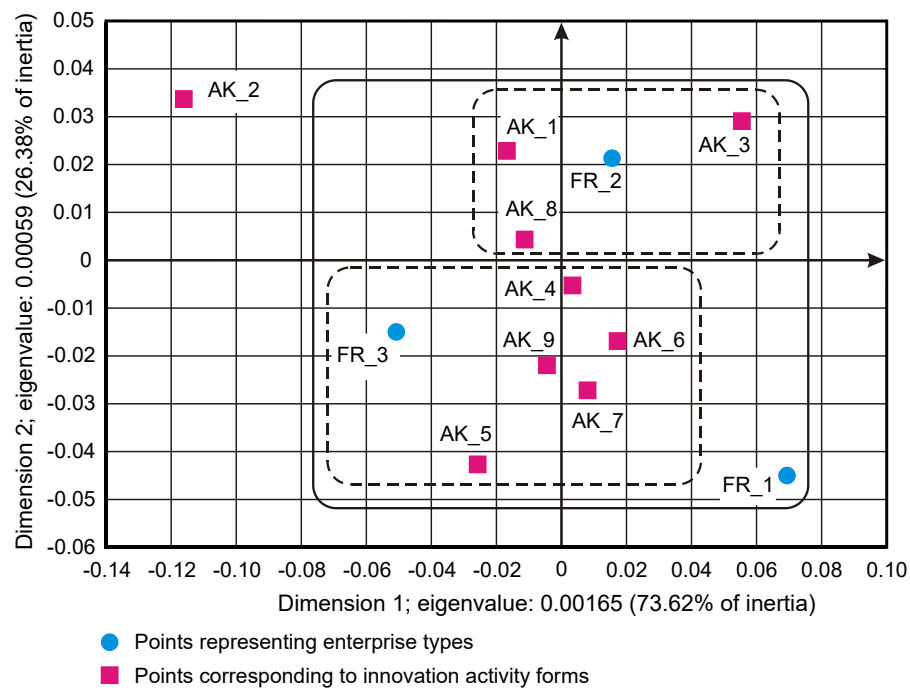

Figure 3. Biplot showing the co-occurrence of the forms of innovation activity and the types of enterprises

\section{Decisions of companies regarding innovations implemented}

The exogenous innovation shock which took place during the global financial crisis influenced companies' decisions in terms of innovations to be implemented. Since its effects persisted in 2012-2014, one has to pose a research question about the impact of such new economic conditions on the types of innovation undertaken by firms depending on their type. To this end, Table 8 is provided, including the number of product/process, organizational and marketing innovations depending on enterprise size.

Table 8. Contingency table presenting the types of innovation implemented depending on enterprise size, and the variable codes

\begin{tabular}{lllrrr}
\hline $\begin{array}{l}\text { Types of } \\
\text { innovation }\end{array}$ & Variables & Code & FR_1 & FR_2 & FR_3 \\
\hline $\begin{array}{llllll}\text { Product } \\
\text { innovations }\end{array}$ & Products - innovative goods & IWR & 295 & 1152 & 664 \\
Process & Products - innovative services & IUS & 91 & 243 & 125 \\
innovations & New innovative production processes & PRC_1 & 266 & 944 & 532 \\
& New innovative production logistics processes & PRC_2 & 81 & 257 & 246 \\
& New innovative management processes & PRC_3 & 128 & 521 & 387 \\
\hline
\end{tabular}




\begin{tabular}{|c|c|c|c|c|c|}
\hline $\begin{array}{l}\text { Types of } \\
\text { innovation }\end{array}$ & Variables & Code & FR_1 & FR_2 & FR_3 \\
\hline \multirow[t]{3}{*}{$\begin{array}{l}\text { Organizational } \\
\text { innovations }\end{array}$} & $\begin{array}{l}\text { New methods under the principles of } \\
\text { operation adopted }\end{array}$ & OR_1 & 164 & 555 & 422 \\
\hline & $\begin{array}{l}\text { New methods of distribution of tasks and } \\
\text { decision-making powers among employees }\end{array}$ & OR_2 & 157 & 439 & 374 \\
\hline & $\begin{array}{l}\text { New organizational methods in terms of } \\
\text { relations with the environment }\end{array}$ & OR_3 & 98 & 240 & 243 \\
\hline \multirow[t]{4}{*}{$\begin{array}{l}\text { Marketing } \\
\text { innovations }\end{array}$} & $\begin{array}{l}\text { Significant changes in the design/construction } \\
\text { and/or packaging of goods and/or services }\end{array}$ & IMK_1 & 126 & 365 & 285 \\
\hline & New media or product promotion methods & IMK_2 & 108 & 301 & 244 \\
\hline & $\begin{array}{l}\text { New methods in terms of product distribution } \\
\text { or sales channels }\end{array}$ & IMK_3 & 66 & 211 & 147 \\
\hline & New methods of pricing goods and services & IMK_4 & 105 & 268 & 155 \\
\hline
\end{tabular}

To verify the foregoing, a chi-square test for independence was performed. This required the following research hypotheses to be tested:

$H_{0}$ : types of innovation implemented do not depend on the enterprise size; $H_{1}$ : types of innovation implemented depend on the enterprise size.

Table 9 illustrates the results of the null hypothesis verification concerning the independence of innovation types from company sizes. They show that the null hypothesis should be rejected in favor of the alternative hypothesis $H_{1}$, which means that the types of innovation implemented depend on the enterprise size.

Table 9. Results of the verification of the null hypothesis regarding the independence of innovation types from enterprise size

\begin{tabular}{llll}
\hline$\chi^{2}$ value & Degrees of freedom & Significance level $(\alpha)$ & $p$-value \\
\hline 117.36 & 22 & 0.05 & 0.000 \\
Decision & Since $p<\alpha, H_{0}$ needs to be rejected in favor of $H_{1}$ \\
\hline
\end{tabular}

To clarify the relationships between types of innovation implemented and sizes of enterprise, a correspondence analysis was carried out. Table 10 presents the coordinates of the rows being types of innovation activity pursued as well as the coordinates of the columns containing sizes of companies. Again, this solution's quality is the best, i.e. equal to one, so the two-dimensional biplot accurately represents the co-occurrence of the studied phenomena. 
Table 10. Coordinates of the rows (types of innovation activity) and the columns (enterprise sizes) with the mass and quality measures

\begin{tabular}{|c|c|c|c|c|}
\hline \multicolumn{5}{|c|}{ Row coordinates } \\
\hline \multirow[t]{2}{*}{ Row } & \multicolumn{2}{|c|}{ Dimension } & \multirow[t]{2}{*}{ Mass } & \multirow[t]{2}{*}{ Quality } \\
\hline & Axis 1 & Axis 2 & & \\
\hline IWR & -0.082 & -0.043 & 0.192 & 1.000 \\
\hline IUS & -0.133 & 0.117 & 0.042 & 1.000 \\
\hline PRC_1 & -0.093 & -0.007 & 0.158 & 1.000 \\
\hline PRC_2 & 0.152 & -0.030 & 0.053 & 1.000 \\
\hline PRC_3 & 0.036 & -0.080 & 0.094 & 1.000 \\
\hline OR_1 & 0.043 & -0.023 & 0.104 & 1.000 \\
\hline OR_2 & 0.090 & 0.030 & 0.088 & 1.000 \\
\hline OR_3 & 0.167 & 0.055 & 0.053 & 1.000 \\
\hline IMK_1 & 0.050 & 0.029 & 0.071 & 1.000 \\
\hline IMK_2 & 0.066 & 0.039 & 0.059 & 1.000 \\
\hline IMK_3 & 0.000 & 0.007 & 0.039 & 1.000 \\
\hline IMK_4 & -0.086 & 0.121 & 0.048 & 1.000 \\
\hline \multicolumn{5}{|c|}{ Column coordinates } \\
\hline \multirow[t]{2}{*}{ Column } & \multicolumn{2}{|c|}{ Dimension } & \multirow[t]{2}{*}{ Mass } & \multirow[t]{2}{*}{ Quality } \\
\hline & Axis 1 & Axis 2 & & \\
\hline FR_1 & -0.014 & 0.123 & 0.153 & 1.000 \\
\hline FR_2 & -0.078 & -0.025 & 0.499 & 1.000 \\
\hline FR_3 & 0.118 & -0.018 & 0.347 & 1.000 \\
\hline
\end{tabular}

Figure 4 shows the co-occurrence of innovation activity types and enterprise sizes. As far as small enterprises (FR_1) are concerned, it shows that they introduced innovative services (IUS) to the local market, simultaneously using new methods of goods and services pricing (IMK_4). Medium-sized enterprises (FR_2) focused on innovative goods (IWR), implemented new innovative production processes (PRC_1), and developed new methods in terms of product distribution or sales channels (IMK_3). On the other hand, large enterprises (FR_3) employed new innovative production logistics processes (PRC_2), implemented all three organizational innovation forms (OR_1, OR_2, OR_3), introduced substantial changes in the design/ construction and/or packaging of goods and/or services (IMK_1) when it comes to marketing innovations, and used new media and/or improved product promotion methods (IMK_2) in their promotion efforts. One needs to note that PRC_3 is relatively isolated, which means that companies rarely use new innovative management processes. These results indicate that the effects of the exogenous innovation shock mostly affected large innovative 
enterprises, which later concentrated primarily on improving production logistics processes as well as on organizational and marketing innovations. The whole burden of product innovation rests on small and medium-sized companies, which were found to be the most resilient to innovation shock.

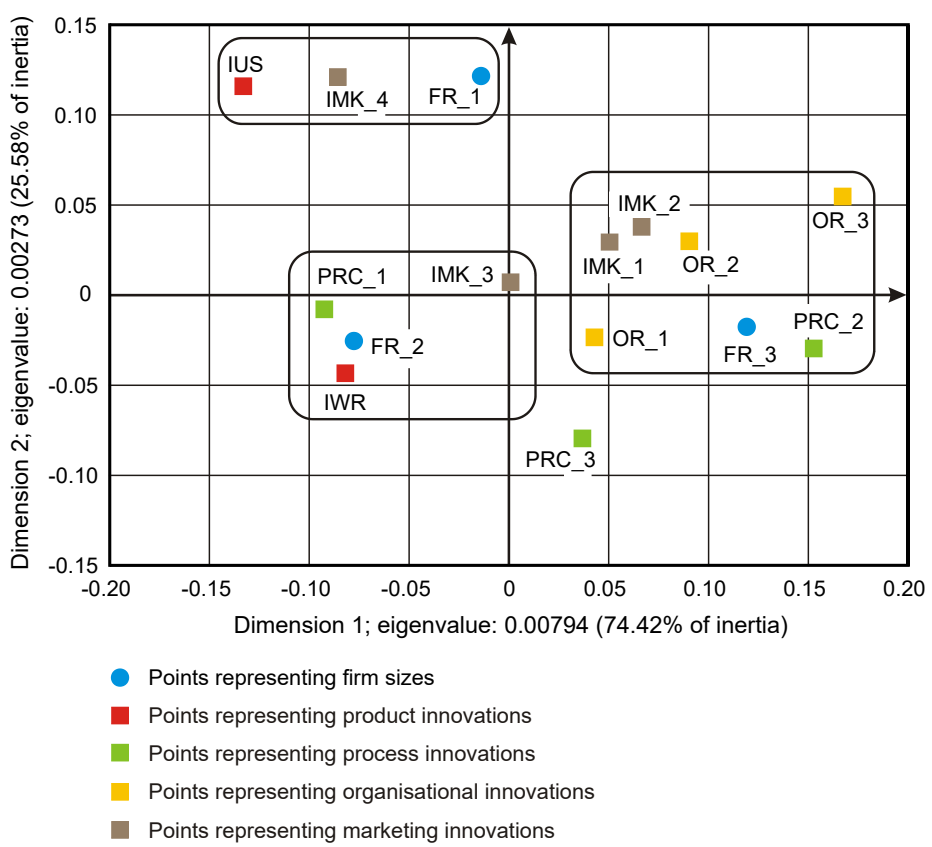

Figure 4. Biplot showing the co-occurrence of the types of innovation and the sizes of enterprises

\section{Methods of product innovation development}

Innovative enterprises may develop products on their own or in cooperation with other national or foreign entities; they can also modify products individually or together with other entities. National and foreign scientific institutions or other domestic companies may take part in developing innovative products as well. Table 11 illustrates the variables for the development and modification of innovative products depending on the enterprise type. This will constitute the basis for further calculations concerning companies' decisions in this regard. 
Table 11. Methods of product innovation development depending on enterprise types and variable codes

\begin{tabular}{|c|c|c|c|c|}
\hline Variables & Code & FR_1 & FR_2 & FR_3 \\
\hline Development of innovative products by the company & IPD_1 & 244 & 943 & 504 \\
\hline $\begin{array}{l}\text { Development of innovative products by the company } \\
\text { and in cooperation with other national entities }\end{array}$ & IPD_2 & 59 & 243 & 196 \\
\hline $\begin{array}{l}\text { Development of innovative products by the company } \\
\text { and in cooperation with other foreign entities }\end{array}$ & IPD_3 & 9 & 76 & 120 \\
\hline $\begin{array}{l}\text { Development of innovative product modifications by } \\
\text { the company and in cooperation with other entities }\end{array}$ & 4 & 22 & 70 & 66 \\
\hline $\begin{array}{l}\text { Development of innovative products by national } \\
\text { scientific institutions }\end{array}$ & IPD_5 & 13 & 51 & 40 \\
\hline $\begin{array}{l}\text { Development of innovative products by foreign } \\
\text { institutions - companies and/or scientific institutions }\end{array}$ & IPD_6 & 14 & 51 & 79 \\
\hline $\begin{array}{l}\text { Development of innovative products by other } \\
\text { domestic companies }\end{array}$ & 7 & 23 & 50 & 4 \\
\hline
\end{tabular}

Source: own elaboration based on questionnaire PNT-02: Report on industrial innovation for 2012-2014, Statistics Poland.

Solving the problem of the relationships between types of companies and their decisions regarding innovative product development and modification requires a chi-square test for independence to be performed. The null hypothesis needs to be tested for the lack of dependencies between the enterprise type and the innovative product development and modification method:

$H_{0}$ : product innovation development methods do not depend on the enterprise type;

$H_{1}$ : product innovation development methods depend on the enterprise type.

Table 12 presents the calculations for the verification of the null hypothesis across the variables studied. Because $p<\alpha$, it is necessary to reject the null hypothesis in favor of the alternative hypothesis, according to which product innovation development methods do depend on the enterprise type.

Table 12. Results of the verification of the null hypothesis regarding the independence of product innovation development methods from enterprise types

\begin{tabular}{llll}
\hline $\boldsymbol{x}^{2}$ value & Degrees of freedom & Significance level $(\alpha)$ & $\boldsymbol{p}$-value \\
\hline 115.63 & 12 & 0.05 & 0.0000 \\
Decision & Since $p<\alpha, H_{0}$ needs to be rejected in favor of $H_{1}$ \\
\hline
\end{tabular}


A more detailed analysis of relationships when it comes to companies' decisions regarding product innovation development methods requires a correspondence analysis to be performed. Table 13 includes the coordinates of the rows (product innovation development methods) and the columns (enterprise types) with the mass of the variables and the solution's quality. The table shows that exactly two dimensions explain the entire inertia of the system studied.

Table 13. Coordinates of the rows (product innovation development methods) and the columns (enterprise types)

\begin{tabular}{|c|c|c|c|c|}
\hline \multicolumn{5}{|c|}{ Row coordinates } \\
\hline \multirow[t]{2}{*}{ Row } & \multicolumn{2}{|c|}{ Dimension } & \multirow[t]{2}{*}{ Mass } & \multirow[t]{2}{*}{ Quality } \\
\hline & Axis 1 & Axis 2 & & \\
\hline IPD_1 & -0.118 & -0.020 & 0.584 & 1.000 \\
\hline IPD_2 & 0.082 & -0.005 & 0.172 & 1.000 \\
\hline IPD_3 & 0.496 & -0.045 & 0.071 & 1.000 \\
\hline IPD_4 & 0.119 & 0.081 & 0.055 & 1.000 \\
\hline IPD_5 & 0.061 & 0.006 & 0.036 & 1.000 \\
\hline IPD_6 & 0.396 & 0.081 & 0.050 & 1.000 \\
\hline IPD_7 & -0.265 & 0.212 & 0.033 & 1.000 \\
\hline \multicolumn{5}{|c|}{ Column coordinates } \\
\hline \multirow[t]{2}{*}{ Column } & \multicolumn{2}{|c|}{ Dimension } & \multirow[t]{2}{*}{ Mass } & \multirow[t]{2}{*}{ Quality } \\
\hline & Axis 1 & Axis 2 & & \\
\hline FR_1 & -0.222 & 0.116 & 0.133 & 1.000 \\
\hline FR_2 & -0.121 & -0.038 & 0.512 & 1.000 \\
\hline FR_3 & 0.258 & 0.012 & 0.355 & 1.000 \\
\hline
\end{tabular}

Figure 5 illustrates the decisions regarding product innovation development methods made by individual enterprise types. Beginning with small enterprises (FR_1), one may notice that they usually use innovative product developments designed by other domestic companies (IPD_7). The so-called imitation effect is used here. It is understandable because those firms have limited access to such production factors as labor and capital. The points representing medium-sized and large enterprises, FR_2 and FR_3, together with their respective decisions, are situated near the origin of the coordinate system, which indicates the presence of a certain standard among the studied enterprises. Medium-sized companies (FR_2) most frequently develop innovative products on their own (IPD_1), as evidenced by the dotted-line frame. In addition, they collaborate in this respect with other national entities (IPD_2) and employ solutions proposed by national scientific 
institutions (IPD_5), as evidenced by the solid-line frame. Large enterprises (FR_3) also choose already-mentioned IPD_2 and IPD_5 characteristic of medium-sized companies, although they also develop innovative product modifications on their own and in cooperation with other entities (IPD_4), outsource innovative product development to foreign institutions (IPD_6), as well as (perhaps) create innovative products on their own and in cooperation with other foreign entities (IPD_3). The last point on the biplot seems to be relatively isolated, thus the corresponding innovative product development method is seldom selected. The relatively large distance between the points representing the enterprise types and the points corresponding to the innovative product development methods is worrying as it means the slow emergence of innovative thought among industrial companies in Poland. Some exceptions here are FR_2 and IPD_1 situated close to each other, which has already been interpreted. This trend looks quite permanent, which necessitates studying barriers to innovation. It may be the case that following the exogenous innovation shock, its effects turned out to be relatively constant. This problem is discussed further in the article.

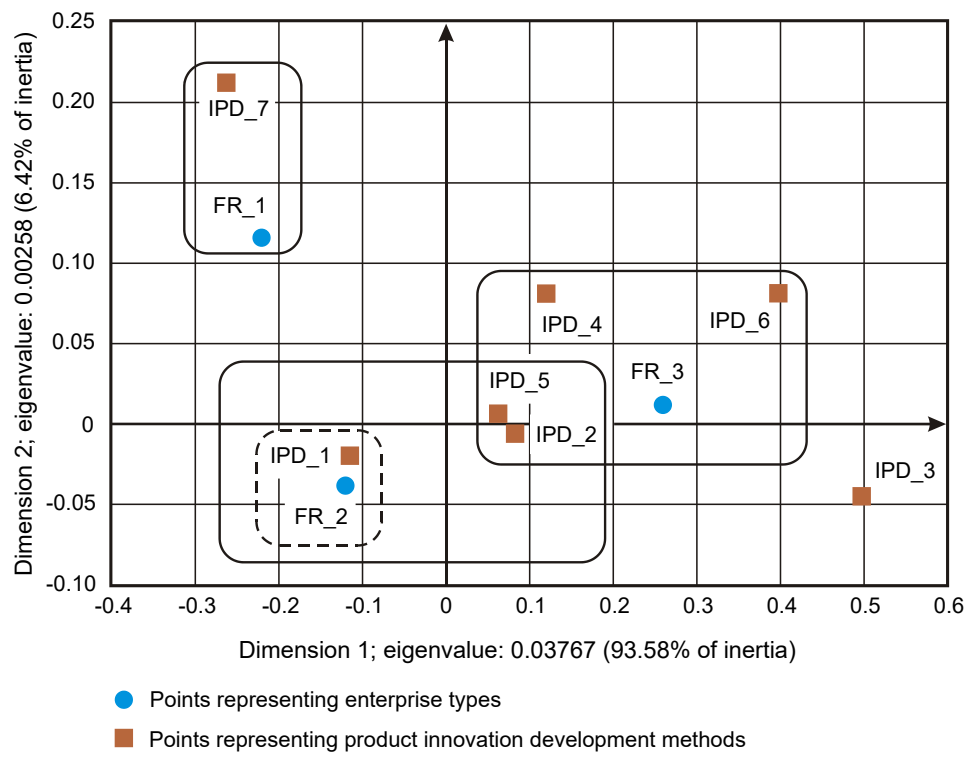

Figure 5. Biplot showing the co-occurrence of the product innovation development methods and the types of companies 


\section{Methods of process innovation development}

Companies can choose from several innovative process development and modification methods. They may develop processes on their own or in cooperation with other national or foreign entities; they may also modify processes on their own or together with other entities. National and foreign companies and/or scientific institutions may take part in developing innovative processes as well. Table 14 illustrates the variables for the development and modification of innovative processes depending on the type of enterprise. This will further underpin calculations concerning process development methods chosen by companies of various types.

Table 14. Process innovation development methods and enterprise types as well as variable codes

\begin{tabular}{|c|c|c|c|c|}
\hline Variables & Code & FR_1 & FR_2 & FR_3 \\
\hline Development of innovative processes by a company & IPC_1 & 209 & 742 & 409 \\
\hline $\begin{array}{l}\text { Development of innovative processes by a company } \\
\text { and in cooperation with other national entities }\end{array}$ & IPC_2 & 56 & 233 & 162 \\
\hline $\begin{array}{l}\text { Development of innovative processes by a company } \\
\text { and in cooperation with other foreign entities }\end{array}$ & IPC_3 & 9 & 73 & 98 \\
\hline $\begin{array}{l}\text { Development of innovative process modifications by } \\
\text { a company and in cooperation with other entities }\end{array}$ & IPC_4 & 32 & 93 & 73 \\
\hline $\begin{array}{l}\text { Development of innovative processes by national } \\
\text { scientific institutions }\end{array}$ & IPC_5 & 15 & 37 & 25 \\
\hline $\begin{array}{l}\text { Development of innovative processes by foreign } \\
\text { institutions -companies and/or scientific institutions }\end{array}$ & IPC_6 & 13 & 69 & 69 \\
\hline $\begin{array}{l}\text { Development of innovative processes by other } \\
\text { domestic companies }\end{array}$ & IPC_7 & 44 & 145 & 64 \\
\hline
\end{tabular}

Source: own elaboration based on questionnaire PNT-02: Report on industrial innovation for 2012-2014, Statistics Poland.

The problem of process innovation development method selection may be solved with a chi-square test for independence. In this case, the following hypotheses are tested:

$H_{0}$ : process innovation development methods do not depend on the enterprise type;

$H_{1}$ : process innovation development methods depend on the enterprise type.

Results of the verification of the null hypothesis regarding the independence of process innovation development methods from enterprise 
types are presented in Table 15. A comparison between the $p$-value and the significance level $\alpha$ suggests that the null hypothesis should be rejected in favor of the alternative hypothesis. Thus, process innovation development and modification methods depend on the firm type.

Table 15. Results of the verification of the null hypothesis regarding the independence of process innovation development methods from enterprise types

\begin{tabular}{llll}
\hline $\boldsymbol{\chi}^{2}$ value & Degrees of freedom & Significance level $(\alpha)$ & $p$-value \\
\hline 71.548 & 12 & 0.05 & 0.0000 \\
Decision & Since $p<\alpha, H_{0}$ & needs to be rejected in favor of $H_{1}$ \\
\hline
\end{tabular}

Table 16 contains the coordinates of the rows representing the available methods of innovative process development and modification as well as the coordinates of the columns corresponding to the types of enterprises. It also includes the mass of individual variables and the statistics of the solution's quality. The total inertia of the system studied is explained in two dimensions.

Table 16. Coordinates of the rows (available innovative process development and modification methods) and the columns (enterprise types)

\begin{tabular}{lcccc}
\hline Row coordinates & \multicolumn{2}{l}{ Mass } & Quality \\
\cline { 2 - 3 } Row & Axis 1 & Axis 2 & \\
\hline IPC_1 & -0.077 & -0.010 & 0.509 & 1.000 \\
IPC_2 & 0.056 & -0.023 & 0.169 & 1.000 \\
IPC_3 & 0.461 & -0.007 & 0.067 & 1.000 \\
IPC_4 & 0.040 & 0.096 & 0.074 & 1.000 \\
IPC_5 & -0.070 & 0.137 & 0.029 & 1.000 \\
IPC_6 & 0.269 & -0.011 & 0.057 & 1.000 \\
IPC_7 & -0.183 & -0.011 & 0.095 & 1.000 \\
\hline Column coordinates & & & \\
\hline Column & \multicolumn{5}{c}{ Dimension } & Mass & Quality \\
\cline { 2 - 3 } & Axis 1 & Axis 2 & & 1.000 \\
\hline FR_1 & -0.219 & 0.076 & 0.142 & 1.000 \\
FR_2 & -0.079 & -0.031 & 0.521 & 1.000 \\
FR_3 & 0.214 & 0.015 & 0.337 & \\
\hline
\end{tabular}

The biplot shown in Figure 6 rather clearly differentiates process innovation development methods depending on the enterprise type, which is an additional argument in favour of the alternative hypothesis. Small enterprises (FR_1) modify processes on their own and in cooperation with other entities (IPC_4) 
and use innovative processes developed by national scientific institutions (IPC_5). However, the distances between point FR_1 and points IPC_4 and IPC_5 are quite considerable, which is indicative of the relatively rare use of those solutions. When it comes to medium-sized enterprises (FR_2), there are substantially more available innovative process development methods; they are also used more often, as evidenced by the shorter distances between the point representing medium-sized enterprises and the points corresponding to the selected methods. Such companies develop innovative processes by themselves (IPC_1) and in cooperation with other national entities (IPC_2), but also take advantage of innovative processes developed by other domestic companies (IPC_7). Large enterprises (FR_3) develop innovative processes on their own and in cooperation with other foreign entities (IPC_3) as well as use innovative processes developed by foreign scientific institutions (IPC_6). The solution to the problem proves that in the case of small companies, the exogenous shock effects are still visible and the same partly applies to large enterprises, particularly regarding IPC_3, as evidenced by the relatively large distance between points FR_3 and IPC_3.

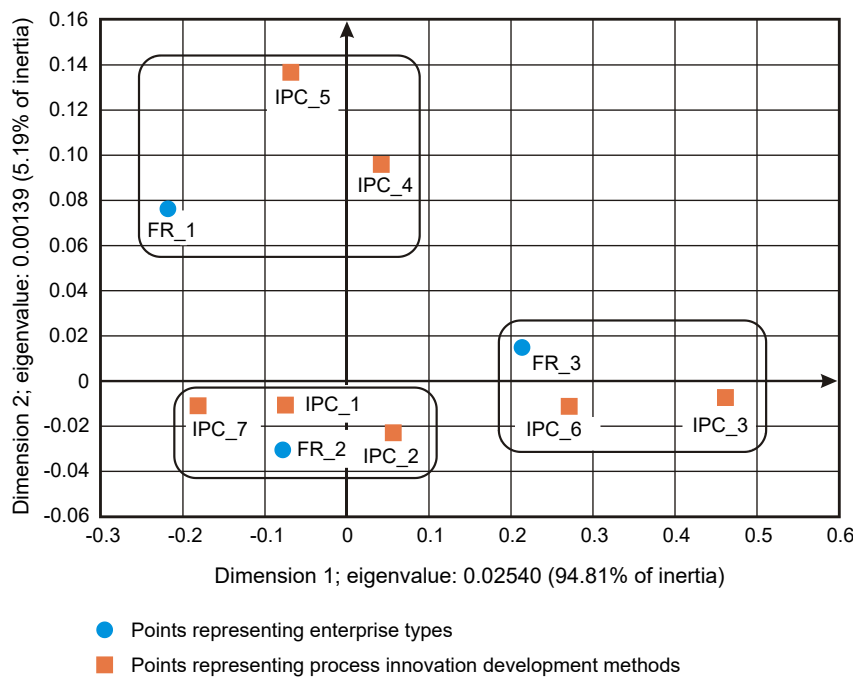

Figure 6. Correspondence map showing the co-occurrence of process innovation development methods and enterprise types

\section{Eco-innovation}

Eco-innovations are a distinct form of innovation activity, and their importance in contemporary economies has been on the rise. The goals of eco-innovation 
include ensuring sustainable development by reducing the adverse effects of industrial activity on the environment, improving natural conditions, as well as using natural resources responsibly. This form of innovation is increasingly relevant to industrial companies, since it indirectly decreases operational costs, provides companies with new growth opportunities, and is of importance in shaping a positive corporate identity. According to the PNT-02 statistical form, two categories of eco-innovation-related environmental benefits are distinguished: those obtained during the period of manufacturing by the enterprise of goods or services and those obtained during the period of use of the purchased product or use of the service by final users. The first group includes decreased material consumption rate, water consumption per product unit, energy consumption rate, and carbon footprint; reduced soil, water, and air pollution; less noise; use of less polluting and less hazardous materials for the environment; less energy from fossil fuels and more energy from renewable sources; recycling of waste, water or materials for the entity's own purpose or for sale. The second group includes decreased energy consumption rate and carbon footprint; lower air, water, and soil pollution; less noise; easier recycling of a product after its use period; as well as extended use period of products thanks to increased durability and tolerance. Table 17 illustrates the forms of eco-innovation depending on enterprise types.

Table 17. Forms of eco-innovation depending on enterprise types, and variable codes

\begin{tabular}{|c|c|c|c|c|c|}
\hline $\begin{array}{l}\text { Environmental } \\
\text { benefits }\end{array}$ & Variables & Code & FR_1 & FR_2 & FR_3 \\
\hline \multirow{6}{*}{$\begin{array}{l}\text { Benefits obtained } \\
\text { during the period } \\
\text { of company's } \\
\text { manufacturing } \\
\text { of goods and/or } \\
\text { services }\end{array}$} & $\begin{array}{l}\text { Decreased material and/or water } \\
\text { consumption rate per product unit }\end{array}$ & EK_1 & 158 & 447 & 332 \\
\hline & $\begin{array}{l}\text { Decreased energy consumption rate } \\
\text { and/or carbon footprint }\end{array}$ & EK_2 & 167 & 507 & 373 \\
\hline & $\begin{array}{l}\text { Decreased soil, water, air pollution } \\
\text { and/or less noise }\end{array}$ & EK_3 & 182 & 439 & 332 \\
\hline & $\begin{array}{l}\text { Use of materials less polluting or less } \\
\text { hazardous to the environment }\end{array}$ & EK_4 & 174 & 381 & 257 \\
\hline & $\begin{array}{l}\text { Less energy from fossil fuels and more } \\
\text { energy from renewable sources }\end{array}$ & EK_5 & 64 & 104 & 90 \\
\hline & $\begin{array}{l}\text { Recycling of waste, water, and/ } \\
\text { or materials for the entity's own } \\
\text { purposes or for sale }\end{array}$ & EK_6 & 223 & 509 & 352 \\
\hline
\end{tabular}




\begin{tabular}{|c|c|c|c|c|c|}
\hline $\begin{array}{l}\text { Environmental } \\
\text { benefits }\end{array}$ & Variables & Code & FR_1 & FR_2 & FR_3 \\
\hline \multirow{4}{*}{$\begin{array}{l}\text { Benefits obtained in } \\
\text { the period of final } \\
\text { user's use of goods } \\
\text { and/or services } \\
\text { purchased }\end{array}$} & $\begin{array}{l}\text { Decreased energy consumption rate } \\
\text { and/or carbon footprint }\end{array}$ & EK_7 & 172 & 389 & 246 \\
\hline & $\begin{array}{l}\text { Decreased soil, water, air pollution } \\
\text { and/or less noise }\end{array}$ & EK_8 & 168 & 390 & 233 \\
\hline & $\begin{array}{l}\text { Easier recycling of a product after its } \\
\text { use period }\end{array}$ & EK_9 & 136 & 284 & 160 \\
\hline & $\begin{array}{l}\text { Extended product use period thanks to } \\
\text { increased durability and tolerance }\end{array}$ & EK_10 & 189 & 385 & 213 \\
\hline
\end{tabular}

Source: own elaboration based on questionnaire PNT-02: Report on industrial innovation for 2012-2014, Statistics Poland.

Determining the relationships between the form of eco-innovation and an enterprise type requires a chi-square test for independence to be carried out. To this end, the following hypotheses were taken into consideration:

$H_{0}$ : forms of eco-innovation do not depend on the type of enterprise; $H_{1}$ : forms of eco-innovation depend on the type of enterprise.

Results of the verification of the null hypothesis regarding the independence of eco-innovation form choice from enterprise types are presented in Table 18. The $p$-value is considerably lower than the significance level $\alpha$, so $H_{0}$ has to be rejected in favor of the alternative hypothesis. Therefore, the form of eco-innovation depends on the type of enterprises.

Table 18. Results of the verification of the null hypothesis regarding the independence of eco-innovation form choice from enterprise types

\begin{tabular}{llll}
\hline $\boldsymbol{\chi}^{2}$ value & Degrees of freedom & Significance level $(\alpha)$ & $\boldsymbol{p}$-value \\
\hline 55.228 & 18 & 0.05 & 0.0001 \\
Decision & Since $p<\alpha, H_{0}$ needs to be rejected in favor of $H_{1}$ \\
\hline
\end{tabular}

Table 19 shows the coordinates of the rows corresponding to ecoinnovation forms, as well as the coordinates of the columns associated with enterprise types. It also shows the row and column mass, as well as the statistics of the solution's quality. Two dimensions allow for full representation of the total inertia of the system. 
Table 19. Coordinates of the rows (forms of eco-innovation) and the columns (enterprise types)

\begin{tabular}{|c|c|c|c|c|}
\hline \multicolumn{5}{|c|}{ Row coordinates } \\
\hline \multirow[t]{2}{*}{ Row } & \multicolumn{2}{|c|}{ Dimension } & \multirow[t]{2}{*}{ Mass } & \multirow[t]{2}{*}{ Quality } \\
\hline & Axis 1 & Axis 2 & & \\
\hline EK_1 & -0.095 & 0.010 & 0.116 & 1.000 \\
\hline EK_2 & -0.112 & 0.025 & 0.130 & 1.000 \\
\hline EK_3 & -0.052 & -0.027 & 0.118 & 1.000 \\
\hline EK_4 & 0.024 & -0.016 & 0.101 & 1.000 \\
\hline EK_5 & 0.037 & -0.149 & 0.032 & 1.000 \\
\hline EK_6 & 0.000 & -0.013 & 0.135 & 1.000 \\
\hline EK_7 & 0.037 & 0.009 & 0.100 & 1.000 \\
\hline EK_8 & 0.049 & 0.030 & 0.098 & 1.000 \\
\hline EK_9 & 0.107 & 0.019 & 0.072 & 1.000 \\
\hline EK_10 & 0.122 & 0.017 & 0.098 & 1.000 \\
\hline \multicolumn{5}{|c|}{ Column coordinates } \\
\hline \multirow[t]{2}{*}{ Column } & \multicolumn{2}{|c|}{ Dimension } & \multirow[t]{2}{*}{ Mass } & \multirow[t]{2}{*}{ Quality } \\
\hline & Axis 1 & Axis 2 & & \\
\hline FR_1 & 0.126 & -0.036 & 0.203 & 1.000 \\
\hline FR_2 & 0.006 & 0.035 & 0.476 & 1.000 \\
\hline FR_3 & -0.089 & -0.029 & 0.321 & 1.000 \\
\hline
\end{tabular}

A graphic representation of the co-occurrence of the studied phenomena was prepared based on Table 19. Figure 7 illustrates the correspondence map presenting the co-existence of eco-innovation forms and enterprise types. Small enterprises (FR_1) focus on environmental benefits achieved during the period of the final user's use of goods or services purchased. In particular, this includes easier recycling of a product after its use period (EK_9) and extended product use period thanks to increased durability and tolerance (EK_10). For medium-sized enterprises (FR_2), there are both benefits obtained in the period of the company's generation of goods and/or services and those obtained in the period of the end user's use of goods and/or services purchased. The first benefit category relates to the use of materials less polluting or less hazardous to the environment (EK_4) as well as the recycling of waste, water and/or materials for a company's own purposes or for sale (EK_6). The second benefit category is achieved through a decreased energy consumption rate and/or carbon footprint (EK_7) and decreased soil, water, air pollution and/ or less noise (EK_8). In the group of large enterprises (FR_3), there are solely environmental benefits obtained in the period of the company's generation of goods and/or services which include decreased material and/or water 
consumption rate per product unit (EK_1), decreased energy consumption rate and/or carbon footprint (EK_2), and decreased soil, water, air pollution and/or less noise (EK_3). It ought to be noted that the most representative enterprise in terms of eco-innovation are medium-sized ones because point FR_2 corresponding to them and points EK_4 and EK_6 as well as EK_7 and EK_8 - corresponding to both benefit categories - are concentrated around the origin of the coordinate system. This means that medium-sized enterprises set the standard of eco-innovation in Poland since their choices are the most diverse ones. In contrast, small and large enterprises have selected their own strategies for eco-innovation and focused on other environmental benefits. What might be found distressing is the relatively large distance between the points representing the enterprise types and the points indicating the decisions regarding individual forms of eco-innovation. This can indicate that the effects of the exogenous innovation shock are still being felt and/or that people are not environmentally aware to a sufficient extent. However, the distances are relatively slightly shorter than those presented in Figures 5-6, which most probably indicates the growing interest of Polish companies in eco-innovation.

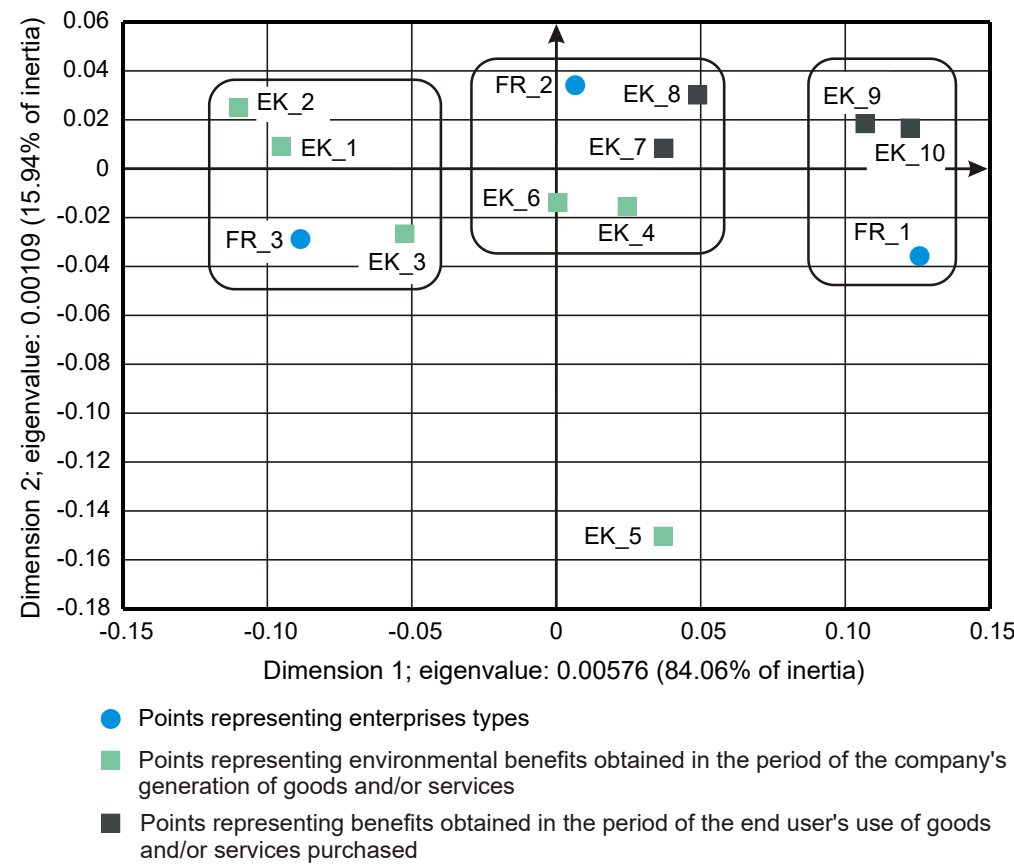

Figure 7. Biplot showing the co-occurrence of eco-innovation forms and types of enterprises 


\section{Barriers to innovation}

Barriers to innovation are an important factor hindering the economic growth of a country; thus, their causes should be researched thoroughly. The firms that are persistent innovators may perceive such barriers in a different way than occasional innovators, which affects differences in the frequency of innovation implementation (Wziątek-Kubiak, Pęczkowski, \& Balcerowicz, 2011). The reasons behind the lack of interest in innovation and the occurrence of barriers to innovation include the impossibility to fund innovation with a company's own funds or from external sources in the form of bank loans or funds from private equity (including venture capital), the lack of adequately qualified personnel, difficulties in obtaining public grants or subsidies for innovation, the lack of business partners, uncertain market demand for innovation concepts, as well as high market competition. Table 20 illustrates the barriers to innovation and their significance to enterprises.

Table 20. Barriers to innovation and their significance for enterprises, and variable codes

\begin{tabular}{|c|c|c|c|c|c|}
\hline \multirow[b]{2}{*}{ Variables } & \multirow[b]{2}{*}{ Code } & \multicolumn{4}{|c|}{ Degree of significance } \\
\hline & & $\begin{array}{c}\text { A } \\
\text { (high) }\end{array}$ & $\begin{array}{c}\text { B } \\
\text { (average) }\end{array}$ & $\begin{array}{c}\text { C } \\
\text { (low) }\end{array}$ & $\begin{array}{c}\text { D } \\
\text { (insignificant) }\end{array}$ \\
\hline $\begin{array}{l}\text { Impossibility to fund innovation } \\
\text { with company's own funds }\end{array}$ & BRI_1 & 1701 & 1325 & 720 & 2872 \\
\hline $\begin{array}{l}\text { Impossibility to fund innovation } \\
\text { from external sources in the } \\
\text { form of bank loans or funds } \\
\text { from private equity (including } \\
\text { venture capital) }\end{array}$ & BRI_2 & 1180 & 1571 & 856 & 3011 \\
\hline $\begin{array}{l}\text { Lack of adequately qualified } \\
\text { personnel }\end{array}$ & BRI_3 & 704 & 1611 & 1105 & 3198 \\
\hline $\begin{array}{l}\text { Difficulties in obtaining } \\
\text { public grants or subsidies for } \\
\text { innovation }\end{array}$ & BRI_4 & 1214 & 1329 & 815 & 3260 \\
\hline Lack of business partners & BRI_5 & 761 & 1546 & 997 & 3314 \\
\hline $\begin{array}{l}\text { Uncertain market demand for } \\
\text { innovation concepts }\end{array}$ & BRI_6 & 1068 & 1584 & 881 & 3085 \\
\hline High market competition & BRI_7 & 1077 & 1568 & 869 & 3104 \\
\hline
\end{tabular}

Table 20 contains the variables in the form of barriers to innovation as well as four degrees of their significance for companies. However, this 
information is insufficient to determine their relationship with individual types of enterprises. Correspondence analysis allows for defining supplementary points that help establish the co-occurrences between variables. Table 21 contains supplementary points standing for enterprise types depending on the level of significance of individual barriers to innovation.

Table 21. Supplementary points standing for enterprise types depending on the level of significance of individual barriers to innovation

\begin{tabular}{lcccc}
\hline Variables & A (high) & B (average) & C (low) & $\begin{array}{c}\text { D } \\
\text { (insignificant) }\end{array}$ \\
\hline FR-1 & 869 & 550 & 272 & 1234 \\
FR-2 & 751 & 673 & 368 & 1392 \\
FR-3 & 81 & 102 & 80 & 246 \\
\hline
\end{tabular}

To determine relationships between barriers to innovation and enterprise types, a chi-square test for independence was performed. This required the formulation of the following research hypotheses:

$H_{0}$ : barriers to innovation do not depend on enterprise types;

$H_{1}$ : barriers to innovation depend on enterprise types.

Table 22 presents the results of the verification of the $H_{0}$ hypothesis regarding the independence of barriers to innovation from enterprise types. The inequality $\mathrm{p}<\alpha$ points to the necessity of rejecting the null hypothesis in favor of the alternative hypothesis. Therefore, it needs to be concluded that barriers to innovation depend on the enterprise type.

Table 22. Results of the verification of the $H_{0}$ hypothesis regarding the independence of barriers to innovation from enterprise types

\begin{tabular}{llll}
\hline $\boldsymbol{\chi}^{2}$ value & Degrees of freedom & Significance level $(\alpha)$ & $p$-value \\
\hline 803.945 & 18 & 0.05 & 0.0000 \\
Decision & Since $p<\alpha, H_{0}$ needs to be rejected in favor of $H_{1}$ \\
\hline
\end{tabular}

Table 23 shows the coordinates of the rows representing the barriers to innovation and enterprise types as well as the coordinates of the columns corresponding to four degrees of significance of these barriers for innovative companies studied. There is also the row and column mass as well as the statistics of the solution's quality. In this case, the row and column quality is slightly lower than one, and the only exception is the barrier of excessively high market competition (BRI_7), whose quality is 0.523 . This allows one to 
present $98.51 \%$ of the total inertia of the system studied in two dimensions, which is still a very good result $(98.51 \%>75 \%)$.

Table 23. Coordinates of the rows (barriers to innovation and enterprise types) and the columns (degree of significance of individual barriers to innovation)

\begin{tabular}{lcccc}
\hline Row coordinates & \multicolumn{3}{c}{ Mass } & Quality \\
\cline { 2 - 3 } Row & Axis 1 & Axis 2 & \\
\hline BRI_1 & -0.246 & 0.005 & 0.143 & 0.994 \\
BRI_2 & -0.031 & 0.032 & 0.143 & 0.964 \\
BRI_3 & 0.173 & 0.011 & 0.143 & 0.972 \\
BRI_4 & -0.055 & -0.061 & 0.143 & 0.995 \\
BRI_5 & 0.138 & -0.024 & 0.143 & 0.999 \\
BRI_6 & 0.013 & 0.022 & 0.143 & 0.775 \\
BRI_7 & 0.008 & 0.015 & 0.143 & 0.523 \\
FR_1 & -0.246 & 0.005 & 0.143 & 0.994 \\
FR_2 & -0.031 & 0.032 & 0.143 & 0.964 \\
FR_3 & 0.173 & 0.011 & 0.143 & 0.972 \\
\hline Column coordinates & & & \\
\hline Column & \multicolumn{5}{c}{ Dimension } & Mass & \\
\cline { 2 - 4 } & Axis 1 & Axis 2 & 0.999 \\
A & -0.277 & 0.007 & 0.166 & 0.968 \\
B & 0.058 & 0.047 & 0.227 & 0.918 \\
C & 0.124 & 0.010 & 0.135 & 0.978 \\
D & 0.035 & -0.028 & 0.472 & \\
\hline
\end{tabular}

Figure 8 illustrates a biplot indicating the co-occurrence of the points standing for barriers to innovation, degrees of their significance and enterprise types. For small enterprises (FR_1), of utmost importance is the barrier of impossibility to finance innovation from the company's internal sources (BRI_1), whose degree of significance is high (A). For medium-sized enterprises (FR_2), the situation is similar as far as BRI_1 is concerned, but BRI_2 is also present - the impossibility to fund innovation from external sources, as well as BRI_6 - uncertain market demand for innovation concepts, and BRI_7-high market competition. The distances of three points BRI_2, BRI_6, and BRI_7 from point B, standing for their average degree of significance, does not imply particular significance of these barriers to the development of medium-sized enterprises. Perhaps these barriers did not prove too burdensome in terms of the innovation activity they pursued. The concentration of these barriers in a relatively limited space suggests 
that companies perceive them in a similar way. When it comes to large enterprises (FR_3), the following barriers proved to be of no significance (D): BRI_4 - difficulties in obtaining public grants or subsidies for innovation and BRI_5 - lack of business partners. The distances between the remaining points representing barriers to innovation and point FR_3 means that large companies do not find the said barriers to be a significant factor restricting their innovation activity. Thus, possible restrictions of innovation activity must stem from other reasons. However, for all enterprises, barrier BRI_3 - lack of adequately qualified personnel - turned out to be of low significance (C), as highlighted by the dotted-line frame. This means that companies engaged in industrial processing in Poland do not experience shortages of well-qualified workers.

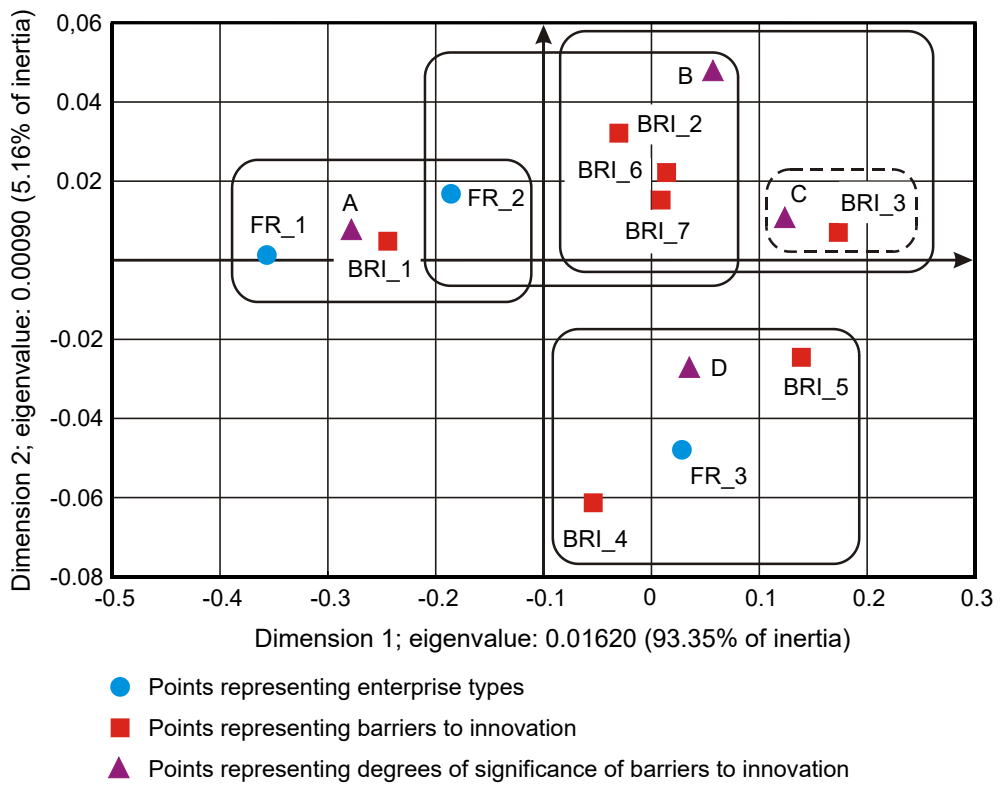

Figure 8. Biplot illustrating the co-occurrence of barriers to innovation and degrees of their significance to individual enterprise types

\section{DISCUSSION}

The calculations presented above prove that a majority of the variables describing the innovativeness of companies engaged in industrial processing depends on their type, i.e. on whether they are small, medium-sized or 
large. This relationship is clearly visible when it comes to market geographic coverage since it is directly proportional to enterprise size (Figure 2). The literature concerning this subject also lists other development factors, affecting the geographical scope of the market of innovative enterprises, which are particularly important from the perspective of their presence on international markets, such as using business counseling services or the ability to quickly absorb business knowledge (Stawasz, 2019).

The only exception here is the independence of forms of innovation activity from enterprise types, which is logical as only innovative companies were studied. However, medium-sized and large enterprises innovate more actively, since almost all the points in Figure 3 corresponding to the forms of innovation activity revolve around the points representing these companies. Small enterprises have the greatest difficulties with innovating; it is understandable, bearing in mind that they have limited financial resources. A similar relationship occurs when it comes to innovation diversity, where medium-sized and large enterprises prevail (Figure 4). However, small and medium-sized enterprises are the most flexible and resilient to exogenous innovation shock effects, as evidenced by their leadership in product/process innovation in subsequent years. On the other hand, large companies focused at that time primarily on improving production logistics processes as well as organizational and marketing innovations.

As far as product innovation development methods are concerned, the widest diversity of approaches is characteristic of large enterprises (Figure 5). Small and medium-sized firms focus mainly on selected development methods, i.e. small enterprises imitate and use solutions developed by other national companies, whereas medium-sized enterprises develop innovative products on their own. Process innovation development methods are considerably diverse, depending on enterprise types (Figure 6). Here, the main role is played by medium-sized and large enterprises because they use multiple development methods, though small companies are not far behind in this regard - they modify innovative processes by themselves and in cooperation with other entities and use innovative processes developed by national scientific institutions.

Currently, the most important aspect of innovation activity pursued by enterprises is eco-innovation. This form of innovation contributes to sustainable development through neutralization of the adverse impact of industrial processing on the environment, protects the environment and fosters more reasonable and responsible use of natural resources. Ecoinnovations bring a variety of benefits to companies implementing them and have been slowly becoming the core goal of innovation activity. In terms of implementing various forms of eco-innovation, there are also medium-sized 
enterprises that achieve the greatest advantages through them (Figure 7). In addition, it is a crucial field of innovation activity for large companies. It needs to be added that small enterprises are active in this area as well because they implement eco-innovations pertaining both to the recycling of product after their use period and to extending the product use period thanks to increased product durability and tolerance.

The focus of Polish enterprises on eco-innovations implies a willingness to make a sharp jump forward to skip over certain phases in economic development related to traditional innovations and demonstrates an experience-based learning process. Most probably, such a situation is the effect of an environmentally-friendly economic policy, whose popularity is constantly growing in the European Union.

Considering the barriers to innovation, it has to be noted that most of them are not too burdensome for large companies; they do not find it difficult to obtain public grants or subsidies for innovation, nor do they complain about a lack of business partners (Figure 8). These barriers do not limit small and medium-sized enterprises to a substantial extent either, as the only serious difficulty for them is the impossibility to fund innovation on their own. Medium-sized enterprises indicate a certain problem with funding innovation from external sources, in the form of credits or funds under private equity, but the degree of significance of this barrier is not high. A majority of the barriers are concentrated in a limited area of the biplot shown in Figure 8 , and their degree of significance is believed by companies to be average or low. The fact that companies engaged in industrial processing find barriers to innovation of relatively slight importance means that the exogenous innovation shock effects are slowly fading away.

\section{CONCLUSION}

The innovation activity of companies involved in industrial processing in Poland, despite a slow decrease in the significance of barriers to innovation, shows certain signs of stagnation in 2012-2014. A thorough analysis of the biplot presented in Figure 3 demonstrates that even though the general conclusion of the independence of an innovation activity form of an enterprise type is valid, relatively large distances between the points corresponding to the enterprises types and to the innovation activity forms mean that companies generally avoid decisive innovation-related action; this particularly applies to small enterprises. A similar phenomenon may be observed on the biplot shown in Figure 5, where large distances are generally visible between the points corresponding to the product innovation development 
methods and to the enterprise types. What is more, the points on the biplot in Figure 6 representing the process innovation development methods and the enterprise types are large distances from each other. Therefore, there is a certain reluctance towards innovation, although companies are clearly aware of the need to innovate. This problem can be explained in multiple ways. First of all, the current risks associated with innovating might be considered quite high by companies, as a result of which they can wait for a substantial improvement in the economic situation. The other explanation hinges upon the negative experiences from the innovation shock of 2008-2010, which can lead to the emergence of some psychological barriers and excessive caution in developing and implementing innovations. This is to some extent inconsistent with a low level of significance of a majority of the barriers to innovation reported by companies (Jakimowicz \& Rzeczkowski, 2019). The detailed analysis of the biplot shown in Figure 7 does not seem to fully support either of the aforementioned explanations as it illustrates the co-occurrence of various forms of eco-innovation and enterprise types. Thus, another, more probable explanation of these differences needs to be found.

Eco-innovation is a reasonably new kind of innovation activity; not only does it bring industrial companies measurable benefits, but it is also supposed to protect the environment from industrial activities and reinforces the positive corporate identity of the company. The importance of ecoinnovation is emphasized in Oslo Manual 2018 (OECD/Eurostat, 2018, p. 166) which positions the development of environmentally friendly products as one of the factors pertaining to the innovation objectives and outcomes. Eco-innovation varies considerably from other forms of innovation so it is reasonable - with regard to the studies conducted - to divide innovation into eco-innovation and traditional innovation. A quite characteristic feature of the biplot in Figure 7 is also the fact that the points representing individual forms of eco-innovation are situated at relatively short distances from the points corresponding to enterprise types. In addition, there is a distinctive group of points associated with different forms of eco-innovation around each of the enterprise types, which suggests that small, medium-sized and large enterprises specialize in their respective, and simultaneously distinct, forms of eco-innovation. This results in a certain type of specialization and is favorable for the national economy. Ultimately, it has to be concluded that the innovation stagnation observed among firms pertains exclusively to traditional innovation, while eco-innovations are becoming increasingly popular among Polish companies engaged in industrial processing.

The comprehensive study concerning the issue of innovation in Polish enterprises in the industrial processing sector presented in this paper, covering relations between sixty-three variables, is unique in the literature. 
The presented analysis offers many more conclusions and interpretations regarding the investment strategy of enterprises than has been described in the paper. In view of the broad scope of the issue and its complex nature, the paper discusses only basic relations. Biplots and tables included in the paper provide more varied and detailed results, particularly regarding the interpretation of rows and column masses and the point quality. An in-depth analysis of tables and biplots is available to readers without access to the large database of the Central Statistical Office (GUS), providing an opportunity to independently discover and interpret numerous interdependences which may be of interest to them.

\section{Acknowledgments}

The study presented here was conducted as part of the Opus 9 project entitled "Różnicowanie się strategii innowacji polskich przedsiębiorstw przetwórstwa przemysłowego pod wpływem zmian uwarunkowań makroekonomicznych" (Differentiation of innovation strategies of Polish manufacturing firms as an effect of changes in macroeconomic environment) funded by the National Science Centre, Poland, under the Contract No. UMO-2015/17/B/HS4/02742. The statistical data used in the calculations originate from the Statistical Office in Szczecin, which assumes no responsibility for the conclusions reached in the paper.

\section{References}

Antonioli, D., Bianchi, A., Mazzanti, M., Montresor, S., \& Pini, P. (2013). Innovation strategies and economic crisis: Evidence from firm-level Italian data. Economia Politica, 30(1), 15-49. https://doi.org/10.1428/73099

Antonioli, D., \& Montresor, S. (2018). Persistence of innovation in times of crisis: An analysis of Italian firms. Retrieved from https://siecon3607788.c.cdn77.org/sites/siecon.org/files/media_wysiwyg/antoniolimontresor-13.pdf

Balcerowicz, E., Pęczkowski, M., \& Wziątek-Kubiak, A. (2012). Sectoral patterns of innovation: Comparing high and low technology sectors' firms in the New Member States. Economic Studies, 3(74), 293-324.

Baran, M. (2010). Diffusion of innovations in the systems thinking approach. Journal of Entrepreneurship, Management and Innovation, 6, 16-24 (formerly: Management Business Innovation).

Benzécri, J.P. (1992). Correspondence Analysis Handbook. New York, NY: Marcel Dekker.

Bieńkowska, E. (2015). Wspólny rynek UE nie działa, problemem jest biurokracja. Puls Biznesu. Retrieved from https://www.pb.pl/bienkowskawspolny-rynek-ue-nie-dziala-problemem-jest-biurokracja-789194 
Block, J.H., Fisch, C.O., \& van Praag, M. (2017). The Schumpeterian entrepreneur: A review of the empirical evidence on the antecedents, behaviour and consequences of innovative entrepreneurship. Industry and Innovation, 24(1), 61-95. https://doi.org/10.1080/13662716.2016.1216397

Borg, I., \& Groenen, P.J.F. (2010). Modern Multidimensional Scaling: Theory and Applications. Second edition. New York, NY: Springer Science + Business Media.

Bourdieu, P. (1996). Distinction: A Social Critique of the Judgement of Taste. Cambridge: Harvard University Press.

Building Institutions for Markets (2002). World Development Report 2002. Washington: The World Bank/Oxford University Press.

Cobb, C.W., \& Douglas, P.H. (1928). A theory of production. The American Economic Review, 18(1), 139-165. Supplement: Papers and Proceedings of the Fortieth Annual Meeting of the American Economic Association. https://www.jstor.org/stable/1811556

Commission Regulation (EU) No. 651/2014 of 17 June 2014 declaring certain categories of aid compatible with the internal market in application of Articles 107 and 108 of the Treaty, Official Journal of the European Union, L 187/1, 26.6.2014.

Crudu, R. (2019). The role of innovative entrepreneurship in the economic development of EU member countries. Journal of Entrepreneurship, Management and Innovation, 15(1), 35-60. https://doi. org $/ 10.7341 / 20191512$

Europe 2020: A European strategy for smart, sustainable and inclusive growth. (2010). Brussels: European Commission.

Eurostat. (2019). R\&D expenditure in the EU increased slightly to $2.07 \%$ of GDP in 2017. Retrieved from https://ec.europa.eu/eurostat/ documents/2995521/9483597/9-10012019-AP-EN.pdf

Gałązka, K. (2017). Ekoinnowacje jako element zrównoważonego rozwoju na przykładzie województwa lubelskiego. Zeszyty Naukowe Politechniki Częstochowskiej. Zarzqudzanie, 2(25), 59-72.

Gasz, M. (2014). Strategia Europa 2020 - założenia i perspektywy realizacji. Nierówności Społeczne a Wzrost Gospodarczy, 38(2), 85-97.

Golejewska, A. (2018). Innovativeness of enterprises in Poland in a regional context. Journal of Entrepreneurship, Management and Innovation, 14(1), 29-44. https://doi.org/10.7341/20181412

Greenacre, M.J. (1984). Theory and Applications of Correspondence Analysis. London: Academic Press.

Greenacre, M.J. (2007). Correspondence Analysis in Practice. Second edition. Boca Raton, FL: Chapman \& Hall/CRC.

Greenacre, M.J. (2010). Biplots in Practice. Bilbao: Fundación BBVA.

Hollenstein, H. (2018). Innovation strategies of firms -identification, dynamics and intra-industry heterogeneity. Economics Discussion Papers, No. 2018-24, Kiel Institute for the World Economy. Retrieved from http:// www.economics-ejournal.org/economics/discussionpapers/2018-24 
Hollenstein, H. (2019). Innovation strategies of Swiss firms: Identification, dynamics and intra-industry heterogeneity. Economics: The OpenAccess, Open-Assessment E-Journal, 13(2019-18), 1-61. http://dx.doi. org/10.5018/economics-ejournal.ja.2019-18

Jakimowicz, A., \& Rzeczkowski, D. (2019). Do barriers to innovation impact changes in innovation activities of firms during business cycle? The effect of the Polish Green Island. Equilibrium. Quarterly Journal of Economics and Economic Policy, 14(4). https://doi.org/10.24136/eq.2019.030

Kijek, A. (2018). Wpływ cykli koniunkturalnych na działalność innowacyjną przedsiębiorstw w krajach Unii Europejskiej. Folia Oeconomica. Acta Universitatis Lodziensis, 4(336), 225-238. http://dx.doi. org/10.18778/0208-6018.336.14

Kijek, T. (2012). Innovation capital and its measurement. Journal of Entrepreneurship, Management and Innovation, 8(4), 52-68. https:// doi.org/10.7341/2012844

Lorentzen, T., \& Jakobsen, S-E. (2016). Explaining innovation. An empirical analysis of industry data from Norway. Journal of Entrepreneurship, Management and Innovation, 12(2), 5-28. http://dx.doi. org/10.7341/20161221

MacGregor Pelikánová, R. (2019). R\&D expenditure and innovation in the EU and selected member states. Journal of Entrepreneurship, Management and Innovation, 15(1), 13-34. https://doi.org/10.7341/20191511

North, D.C. (1990). Institutions, Institutional Change and Economic Performance. Cambridge: Cambridge University Press.

OECD/Eurostat. (2018). Oslo Manual 2018: Guidelines for Collecting, Reporting and Using Data on Innovation. 4th Edition. The Measurement of Scientific, Technological and Innovation Activities. Paris/Eurostat, Luxembourg: OECD Publishing. https://doi.org/10.1787/9789264304604-en

Pearson, K. (1900). On the criterion that a given system of deviations from the probable in the case of a correlated system of variables is such that it can be reasonably supposed to have arisen from random sampling. Philosophical Magazine, 5(50), 157-175. https://doi. org $/ 10.1080 / 14786440009463897$

Raport z badania Global Entrepreneurship Monitor - Polska 2017/18. (2018). Warszawa: Polska Agencja Rozwoju Przedsiębiorczości. Retrieved from https://www.parp.gov.pl/storage/publications/pdf/raport\%20z\%20 badania\%20global\%20entrepreneurship\%20monitor_2017_2018.pdf

Srholec, M., Verspagen, B. (2008). The voyage of the beagle in innovation systems land. Explorations on sectors, innovation, heterogeneity and selection. Working Papers on Innovation Studies 20080220, Centre for Technology, Innovation and Culture, University of Oslo. Retrieved from https://www.sv.uio.no/tik/InnoWP/0802_TIKwp_SrholecVerspagen.pdf

Stawasz, E. (2019). Factors that shape the competitiveness of small innovative companies operating in international markets with a particular focus 
on business advice. Journal of Entrepreneurship, Management and Innovation, 15(1), 61-82. https://doi.org/10.7341/20191513

Węgrzyn, G. (2013). Ekoinnowacje w Polsce na tle krajów Unii Europejskiej. Ekonomia i Środowisko, 3(46), 138-148.

Wziątek-Kubiak, A., Balcerowicz, E., \& Pęczkowski, M. (2013). Differentiation of innovation strategies of manufacturing firms in the New Member States: Cluster analysis on firm level data. Argumenta Oeconomica, 2(31), 117-149.

Wziątek-Kubiak, A., \& Pęczkowski, M. (2019). Czynniki ciągłości komercjalizacji innowacji w okresie negatywnego szoku zewnętrznego. Przykład Polski. Bank i Kredyt, 50(1), 21-44. Retrieved from http://bankikredyt.nbp.pl/ content/2019/01/BIK_01_2019_02.pdf

Wziątek-Kubiak, A., Pęczkowski, M., \& Balcerowicz, E. (2011). Occasional and persistent innovators in Poland: An empirical study of obstacles to innovation and their complementarities. Economic Studies, 4(71), 345-380.

\begin{abstract}
Abstrakt
Celem artykułu jest określenie strategii innowacyjnej polskich przedsiębiorstw przetwórstwa przemysłowego $w$ okresie 2012-2014, a więc po negatywnym szoku zewnętrznym, którego eskalacja wystapiła w latach 2008-2010 i zwiqzana była z globalnym kryzysem finansowym. Zakresem badania objęto typy przedsiębiorstw (małe, średnie i duże), zasięg geograficzny rynków zbytu, rodzaje działalności innowacyjnej przedsiębiorstw, wybory przedsiębiorstw $w$ zakresie form wprowadzanych innowacji, sposoby opracowania przez nie innowacji produktowych i procesowych, rodzaje ekoinnowacji najczęściej występujquce w przetwórstwie przemysłowym i bariery innowacyjności. Ogółem weryfikacji statystycznej z wykorzystaniem testu niezależności poddano siedem szczegółowych hipotez badawczych. Następie - ze względu na dużq ilość zmiennych uwzględnionych w badaniu i konieczność uszczegółowienia zależności między nimi - posłużono się analizq korespondencji. Jej istotq jest redukcja wielowymiarowej przestrzeni, w której zachodzq badane zjawiska, do przestrzeni o mniejszej liczbie wymiarów, w tym przypadku dwuwymiarowej. Pozwala to na dogodnq analizę współwystępowania zjawisk na wykresach zwanych biplotami. Odkryto stosunkowo mała skłonność przedsiębiorstw do innowacji i ostrożność w ich podejmowaniu, co może wynikać z względnej trwałości skutków szoku egzogenicznego. Jednocześnie rysuje się wyraźna tendencja do podejmowania w szerszym zakresie ekoinnowacji, przy powolnym zmniejszaniu się - w odczuciu przedsiębiorstw - stopni znaczenia barier innowacyjności. Wnioski praktyczne wynikajqce z badań wskazujq na konieczność zaakcentowania w polityce proinnowacyjnej korzyści wynikajqcych z innowacji, a w szczególności ekoinnowacji, co pozwoli na pokonanie negatywnych skutków szoku zewnętrznego w postaci barier psychologicznych i nadmiernej ostrożności w planowaniu i wdrażaniu innowacji. W artykule zawarto oryginalnq, unikalnq i kompleksowq analizę współzależności między sześćdziesięcioma trzema zmiennymi opisujqcymi działalność innowacyjnq przedsiębiorstw. Wartość artykułu polega więc
\end{abstract}


na nowatorskim i stricte empirycznym ujęciu problemów innowacyjności przedsiębiorstw przetwórstwa przemysłowego, co powoduje, że zaprezentowane w nim badania mogq stać się potencjalnym wzorcem do takich analiz w przyszłości.

Słowa kluczowe: przedsiębiorstwa przetwórstwa przemysłowego, strategia innowacyjna, bariery innowacyjności, ekoinnowacje, analiza korespondencji

\section{Biographical notes}

Aleksander Jakimowicz is an Institute professor of economics at the Department for World Economy, Institute of Economics, Polish Academy of Sciences, Warsaw, Poland. His current research interests include mathematical economics, complexity economics, econophysics, financial markets, nonlinear dynamics in economics, econometrics, economic methodology, and Wikinomics. He has published over 80 scientific papers in leading journals in Poland and abroad and has authored four scientific books: From Keynes to Chaos Theory. Evolution of Business Cycle Theory (Warsaw, 2003, 2005, 2012), Sources of Instability of Market Structures (Warsaw, 2010), Foundations of State Interventionism. Philosophy of Economic History (Warsaw, 2012), and The New Economics. Complex Systems and Homo Compositus (Warsaw, 2016). All of these books were published by Polish Scientific Publishers PWN. He has received numerous awards from universities and professional organizations in Poland.

Daniel Rzeczkowski is presently an assistant professor at the Department of Market and Consumption, Faculty of Economic Sciences, University of Warmia and Mazury in Olsztyn, Poland. He received his Ph.D. degree at this University in 2013. He studies mathematical economics, Wikinomics, econometrics, statistics, information and communications technology, and public administration. His papers have been published in such leading transdisciplinary journals as Acta Physica Polonica A and many more. In 2014, he published his first book, entitled Innovation Potential in the Public Administration Sector (Polish Scientific Publishers PWN, Warsaw 2014). 